\title{
INDICADORES DA EDUCAÇÃO SUPERIOR BRASILEIRA DE 2003 A 2013: DADOS E RESULTADOS DAS POLÍTICAS PÚBLICAS IMPLEMENTADAS
}

\author{
INDICADORES DE EDUCACIÓN SUPERIOR DE BRASIL 2003 A 2013: \\ DATOS Y RESULTADOS DE LAS POLÍTICAS PÚBLICAS IMPLEMENTADAS
}

\author{
CAMARGO, Murilo Silva de \\ murilocamargo@gmail.com \\ UNB - Universidade de Brasília
}

\begin{abstract}
RESUMO O último decênio, de 2003 a 2013, foi marcado por profundas transformações na educação brasileira. Nesse período, o orçamento do Ministério da Educação do Brasil (MEC) triplicou, passando de R\$ 34,9 bilhões para $\mathrm{R} \$ 109,2$ bilhões, em valores corrigidos monetariamente. Em termos de percentual de investimento público total em educação em relação ao Produto Interno Bruto (PIB), passou de 4,5\% em 2003 para 5,7\% em 2009, e para 6,4\% em 2012, sobre um PIB 68\% maior. De fato, o orçamento do Ministério da Educação cresceu, em valores atualizados, $205,7 \%$ no intervalo de tempo em questão. Neste contexto de aumento real do investimento em educação na década, este trabalho se propõe a apresentar as principais políticas públicas para a educação superior planejadas e desenvolvidas no período, bem como acompanhar o desenvolvimento dos principais indicadores que possibilitam realizar uma análise sobre a evolução da educação superior brasileira. Este trabalho aborda os principais indicadores da educação superior brasileira: número de matrículas na graduação, mestrado e doutorado; número de universidades públicas e de câmpus; financiamento da educação superior; recursos para assistência estudantil; avaliação da educação superior; bolsas de mestrado e doutorado; e produção científica. Analisamos ainda o alcance da expansão e os desafios ainda existentes.
\end{abstract}

PALAVRAS-CHAVE: Educação superior. Expansão das universidades federais. Indicadores. Políticas públicas. Taxas de escolarização.

RESUMEN El último decenio, de 2003 a 2013, fue marcado por profundas transformaciones en la educación brasileña. En ese período, el presupuesto del Ministerio de la Educación de Brasil (MEC) triplicó, pues pasó de R\$34,9 mil millones para $\mathrm{R} \$ 109,2$ mil millones - valores corregidos monetariamente. En términos de porcentaje de inversión pública total en educación, en lo que concierne al Producto Interno Bruto (PIB), la cifra pasó de 4,5\% en 2003 para $5,7 \%$ en 2009 , y para $6,4 \%$ en 2012 , sobre un PIB $68 \%$ mayor. De hecho, el presupuesto del Ministerio de la Educación aumentó 205,7\% en el intervalo de tiempo citado -nos referimos a valores actualizados. En ese contexto de aumento real de la inversión en educación, este trabajo se propone presentar las principales políticas públicas para la educación superior, planeadas y desarrolladas en el período comprendido entre 2003 y 2013, así como 
acompañar el desarrollo de los principales indicadores que posibilitan realizar un análisis sobre la evolución de la educación superior brasileña. Entre los principales indicadores que este estudio aborda se encuentran: número de matrículas en las licenciaturas, maestrías y doctorados; número de universidades públicas y de campus; financiación/subvención de la educación superior; recursos para la asistencia estudiantil; evaluación de la educación superior; becas de maestría y doctorado; y producción científica. Asimismo, analizamos el alcance de la expansión y los desafíos aún existentes.

PALABRAS-CLAVE: Educación superior. Expansión de las universidades federales. Indicadores. Políticas públicas. Tasas de escolarización

\section{INTRODUÇÃO}

$\mathrm{Na}$ história mais recente do ensino superior brasileiro, podem se destacar três grandes períodos. Entre a década de 1960 e a de 1990 há uma modernização da instituição universitária, tanto em sua estrutura acadêmica e institucional quanto no foco de sua atuação. Nessas décadas se estrutura uma universidade de pesquisa, com um sistema de pós-graduação que se destaca positivamente na América Latina (CUNHA, 2007). No entanto, embora os cursos de graduação e respectivas matrículas tenham tido um importante crescimento naqueles tempos, o acesso à educação superior era limitado pelo sistema de vagas e vestibular e também apresentavam uma qualidade que deixava a desejar.

O segundo período de destaque é o compreendido pelo octênio do governo de Fernando Henrique Cardoso, entre 1994 e 2002, cujo ministro da Educação foi Paulo Renato de Souza. Durante esse período, há um significativo aumento no número de vagas, mas estas se concentram exclusivamente no setor privado, enquanto o setor público federal vê as verbas reduzidas (RIGOTTO; SOUZA, 2005).

O terceiro período se inicia com o governo Lula, em 2003, e se estende até o presente. Este artigo, no entanto, abrange até 2012 para alguns indicadores, e até 2013 para outros. Os indicadores aqui resumidos mostram como é implementada a decisão política de ampliação do acesso ao ensino superior como vetor de diminuição das desigualdades sociais. No primeiro momento, o Programa Universidade para Todos (ProUni) aproveita a existência 
de um grande número de vagas não preenchidas no ensino privado, oferecendo bolsas na forma de renúncia fiscal para seu aproveitamento. Enquanto isso, duas grandes iniciativas de expansão mais demoradas se apoiam nas competências existentes nas universidades federais. A primeira é o Programa de Expansão e Interiorização (Expansão Fase I) destas universidades, que abre novos câmpus em cidades até então sem oferta de ensino superior público, ou mesmo cria universidades novas em cidades do interior do país. A segunda grande iniciativa é o Programa de Reestruturação e Expansão das Universidades Federais Brasileiras (REUNI), que combina organicamente as expansões já iniciadas com a ampliação da capacidade das instalações existentes, com o aumento da oferta de vagas e de novos cursos.

$\mathrm{Na}$ leitura dos indicadores que seguem neste texto deve se considerar que a educação superior brasileira é composta de vários sistemas. No setor público há universidades federais, estaduais e municipais. No setor privado há, também, perfis diferenciados, não discriminados nos dados, que serão apresentados. A maioria dos indicadores se refere às políticas desenvolvidas pelo Governo Federal.

O artigo se inicia com um resumo dos principais indicadores do Censo da Educação Superior de 2013, divulgado em setembro de 2014, para dar um panorama geral da relação entre os setores envolvidos: graduação, pósgraduação, público e privado. Na sequência, se apresenta uma visão da evolução no tempo, relacionando a expansão no setor público e no setor privado. Há ainda um recorte que separa ingressantes e concluintes da graduação e pós-graduação.

A expansão da oferta de vagas nas universidades com o objetivo de diminuir as desigualdades sociais depende também de ações de assistência aos estudantes. São levantados indicadores relativos ao número de bolsas e investimento global, na graduação e na pós-graduação, indicando os programas que foram criados para isto.

Além dos indicadores de investimento, são mostrados os resultados obtidos na criação efetiva de novas vagas, sejam elas na graduação presencial, na graduação a distância ou em cursos de mestrado e doutorado. 


\section{CENSO DA EDUCAÇÃO SUPERIOR}

Em setembro de 2014, o Instituto Nacional de Estudos e Pesquisas Educacionais Anísio Teixeira (INEP/MEC) divulgou o Censo da Educação Superior 2013 (BRASIL, 2014) com os principais resultados deste nível de ensino. Participaram do censo 2.391 Instituições de Ensino Superior (IES) que ofertaram cursos em nível superior. O número total de matrículas apurado foi 7.526.681: destes 203.717 são estudantes de cursos de mestrado e doutorado e 7.305 .977 são estudantes de graduação de 32.049 cursos. Foram registrados 991.010 estudantes concluintes e 2.742.950 estudantes ingressantes em 2013. É importante notar que comparativamente ao ano de 2012, o número de instituições, o número de estudantes ingressantes e o número de estudantes concluintes tiveram uma leve redução. Desde o ano de 2003, esta é a primeira vez que ocorreram quedas nesses indicadores. No entanto, o número total de matrículas teve um aumento de 3,8\% comparado ao ano de 2012. Cabe ressaltar que no sistema brasileiro de educação superior o acesso aos cursos é limitado por vagas ofertadas e cada estudante ingressante corresponde a uma vaga prevista e autorizada para funcionamento no curso.

Todas as instituições e cursos participantes do Censo da Educação Superior 2013 estão devidamente registrados no sistema de cadastro único do Ministério da Educação do Brasil (e-MEC) cujo endereço eletrônico é http://emec.mec.gov.br. As estatísticas básicas, resultantes do Censo 2013, são mostradas na Tabela 1.

Tabela 1 - Estatísticas Gerais da Educação Superior Brasileira organizadas por categoria administrativa

\begin{tabular}{|c|c|c|c|c|c|c|}
\hline \multirow{3}{*}{ Estatísticas Básicas } & \multicolumn{6}{|c|}{ Categoria Administrativa } \\
\hline & \multirow{2}{*}{$\begin{array}{l}\text { Total } \\
\text { Geral }\end{array}$} & \multicolumn{4}{|c|}{ Pública } & \multirow{2}{*}{ Privada } \\
\hline & & Total & Federal & Estadual & Municipal & \\
\hline Número de Instituições & 2.391 & 301 & 106 & 119 & 76 & 2.090 \\
\hline \multicolumn{7}{|c|}{ Educação Superior - Graduação } \\
\hline Cursos & 32.049 & 10.850 & 5.968 & 3.656 & 1.226 & 21.199 \\
\hline Matrículas & 7.305.977 & 1.932 .527 & 1.137 .851 & 604.517 & 190.159 & 5.373 .450 \\
\hline Ingresso Total & 2.742 .950 & 531.846 & 325.267 & 142.842 & 63.737 & 2.211 .104 \\
\hline Concluintes & 991.010 & 229.278 & 115.336 & 82.892 & 31.050 & 761.732 \\
\hline
\end{tabular}




\begin{tabular}{|c|c|c|c|c|c|c|}
\hline Matrículas & 16.987 & 489 & 100 & 208 & 181 & 16.498 \\
\hline \multicolumn{7}{|c|}{ Educação Superior - Pós-Graduação Scricto Sensu } \\
\hline Matrículas & 203.717 & 172.026 & 115.001 & 56.094 & 931 & 31.691 \\
\hline \multicolumn{7}{|c|}{ EDUCAÇÃO SUPERIOR - TOTAL } \\
\hline \multirow{3}{*}{$\begin{array}{l}\text { Matrícula Total } \\
\text { Funções Docentes em } \\
\text { Exercício }{ }^{1,2} \\
\text { Docentes em Exercício }\end{array}$} & 7.526 .681 & 2.105 .042 & 1.252 .952 & 660.819 & 191.271 & 5.421 .639 \\
\hline & 367.282 & 155.219 & 95.194 & 48.275 & 11.750 & 212.063 \\
\hline & 321.700 & 152.166 & 94.354 & 47.823 & 11.459 & 181.302 \\
\hline
\end{tabular}

Notas relativas à tabela:

Fonte: INEP/MEC (BRASIL, 2014)

(1) Corresponde ao número de vínculos de docentes a Instituições de Educação Superior.

(2) Não incluem os docentes que atuam exclusivamente na Pós-Graduação Lato Sensu.

(3) Quantidade de CPFs distintos dos docentes em exercício em cada Categoria Administrativa.

No período de 2003 a 2013, a evolução do atendimento na educação superior, em termos de número de matrículas em cursos de graduação, é mostrada na Figura 1, a seguir, que apresenta os dados segmentados pelos setores público e privado.

Com relação à evolução, ao longo do período estudado, da participação dos setores público e privado no total de matrículas, em cursos de graduação, apresenta-se no gráfico à esquerda na Figura 2, apresentada na sequência, a composição em termos percentuais das matrículas nestes setores ao longo do período em tela. Observou-se uma tendência de redução da participação do setor público ao longo de todos os anos do período analisado, exceto nos dois últimos. Cabe ressaltar que nas séries históricas, apresentadas em Figueiredo (2010), a participação do setor público no ano de 1960 era de $56 \%$ das matrículas, contra os 26\% resultantes do Censo de 2013.

Figura 1 - Número de matrículas em graduação em milhões. Inclui graduação presencial e a distância 


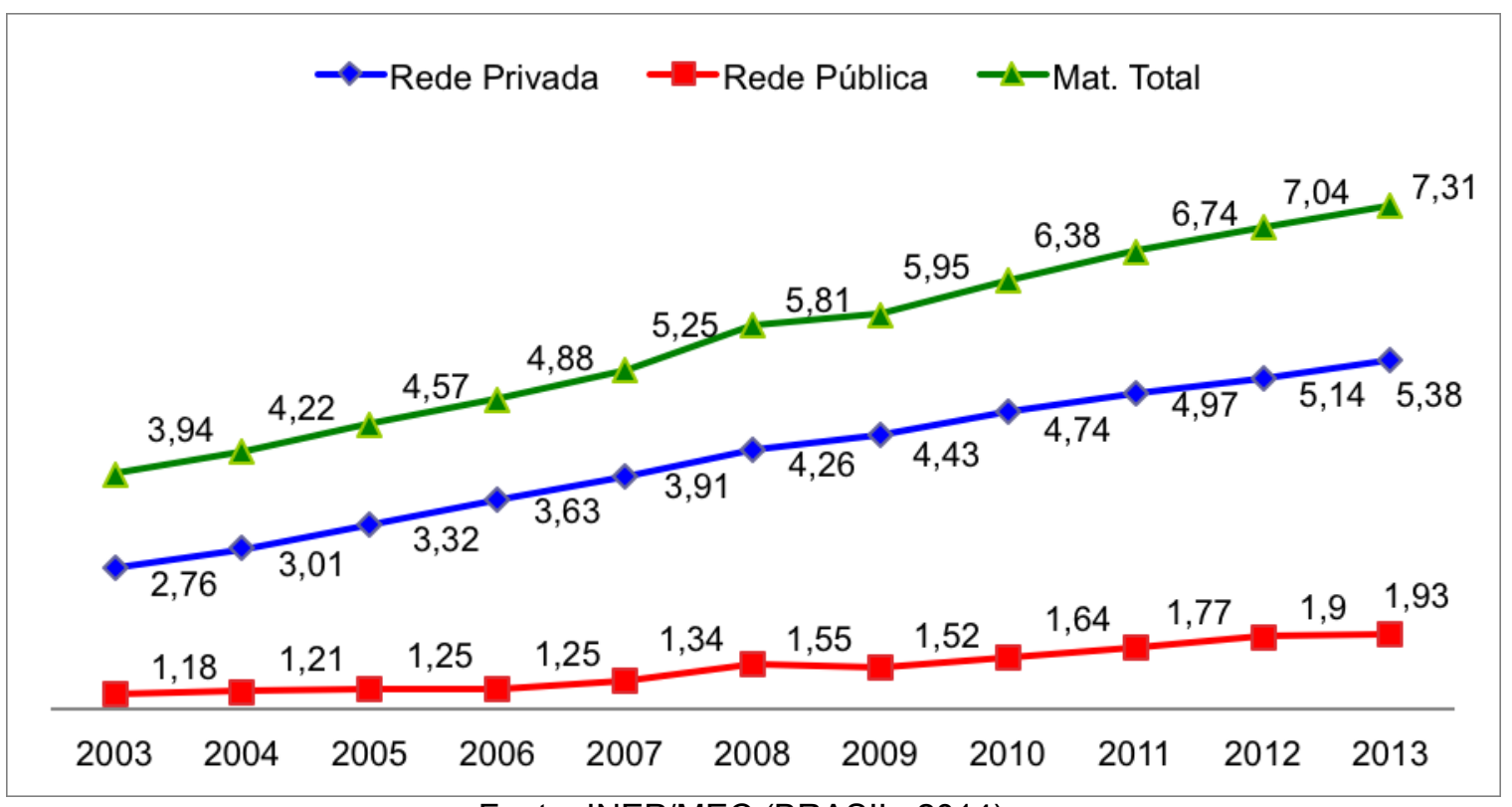

Fonte: INEP/MEC (BRASIL, 2014)

Figura 2 - Percentual de matrículas em graduação (esquerda) e mestrado e doutorado (direita) nos setores público e privado no período de 2003 a 2013 (informações compiladas a partir dos dados do Censo da Educação Superior do INEP/MEC)
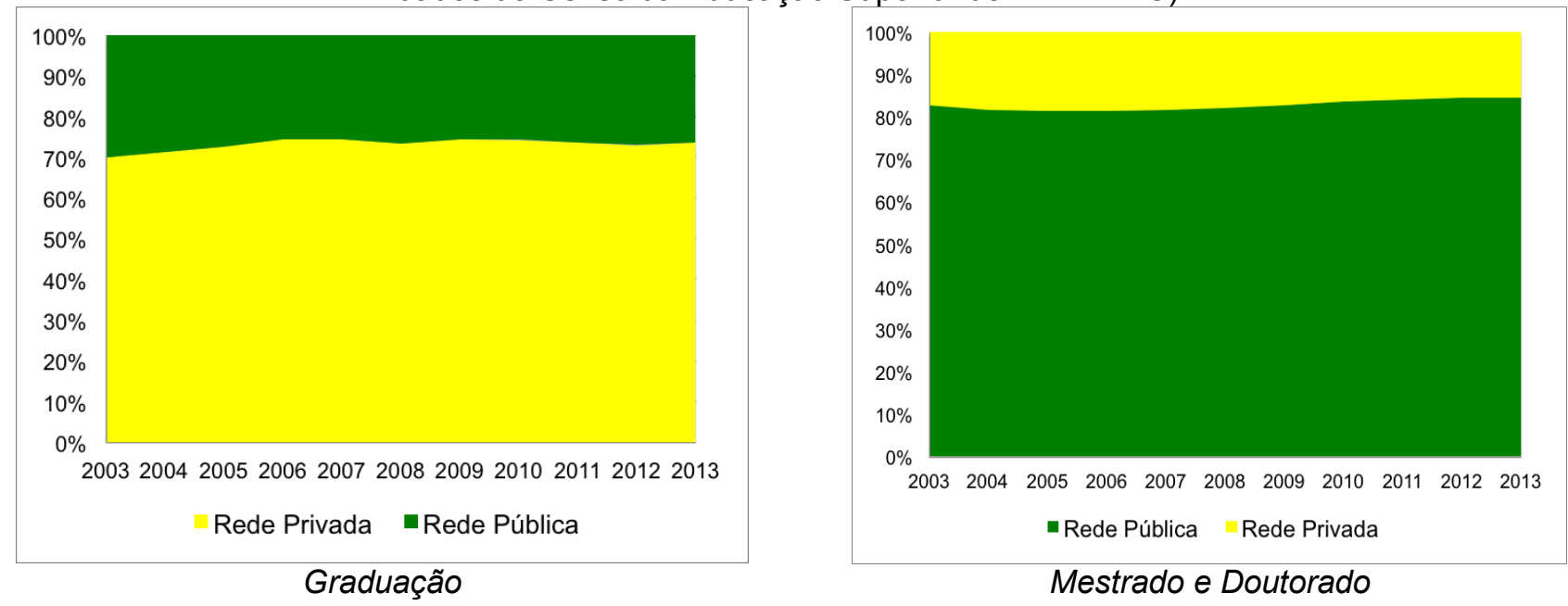

Fonte: Figura elaborada pelo autor a partir de série histórica $(2003$ - 2013) dos dados do Censo da Educação Superior do Brasil disponíveis no site do INEP (www.inep.gov.br)

No período de 2003 a 2013, o número de concluintes da educação superior aumentou $78,8 \%$ e o crescimento é mostrado no gráfico da Figura 3 , a seguir. Observa-se também uma redução do número de concluintes no período de 2012-2013. Uma análise mais detalhada dos dados aponta que esta redução foi sentida principalmente nas instituições privadas. 
Figura 3 - Evolução do número de concluintes por ano na educação superior

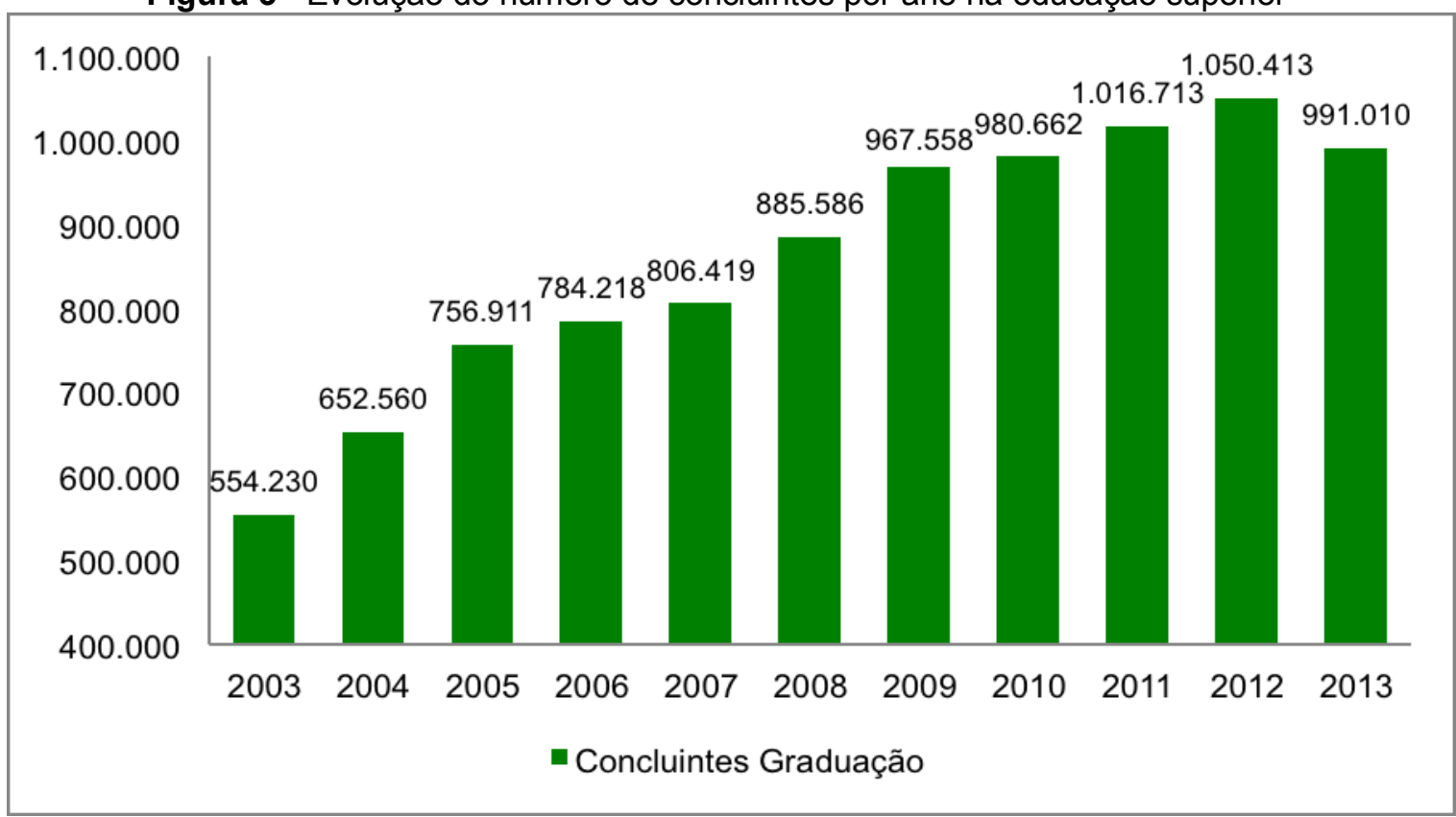

Fonte: INEP/MEC (BRASIL, 2014)

Nas instituições federais de educação superior, o número de matrículas verificado no censo de 2013 foi de 1.252.952, o que representa um aumento de $96,2 \%$ em relação ao ano de 2003. Desse total de matrículas, verifica-se a seguinte composição: $83,4 \%$ de graduação presencial, 9,1\% de graduação a distância e 7,4\% de doutorado e mestrado. A Figura 4 a seguir mostra a evolução desses indicadores.

A aceleração do crescimento de matrículas observada a partir do ano de 2007 deveu-se principalmente aos programas de expansão e interiorização da rede de universidades federais: Expansão Fase I, iniciado em 2004; e REUNI, implementado a partir de 2008 (BRASIL, 2007). Nota-se que, no período de 2007 a 2011, o número de matrículas em cursos de graduação a distância nas universidades federais aumenta em $313 \%$. Esse aumento importante foi devido à implementação do Programa Universidade Aberta do Brasil (UAB), do Ministério da Educação, a partir de 2006. O foco da UAB é a oferta de cursos na modalidade semipresencial pelas universidades públicas em polos no interior brasileiro. Isso explica o importante aumento de matrículas nessa modalidade de cursos nas universidades federais a partir de 2007, apresentado na Figura 4. A grande maioria dos cursos da UAB está voltada para a formação de professores para a Educação Básica. No entanto, o número de matrículas nesses cursos apresenta uma tendência de redução a partir do ano de 2011. 
Isto pode ser explicado pela redução da abertura de novos cursos nos últimos anos e pela conclusão dos cursos iniciados nos dois principais editais do MEC, ocorridos em 2006 e 2008.

Figura 4 - Evolução das matrículas em graduação presencial e a distância, e em cursos de mestrado e doutorado nas instituições federais de educação superior (em milhares)

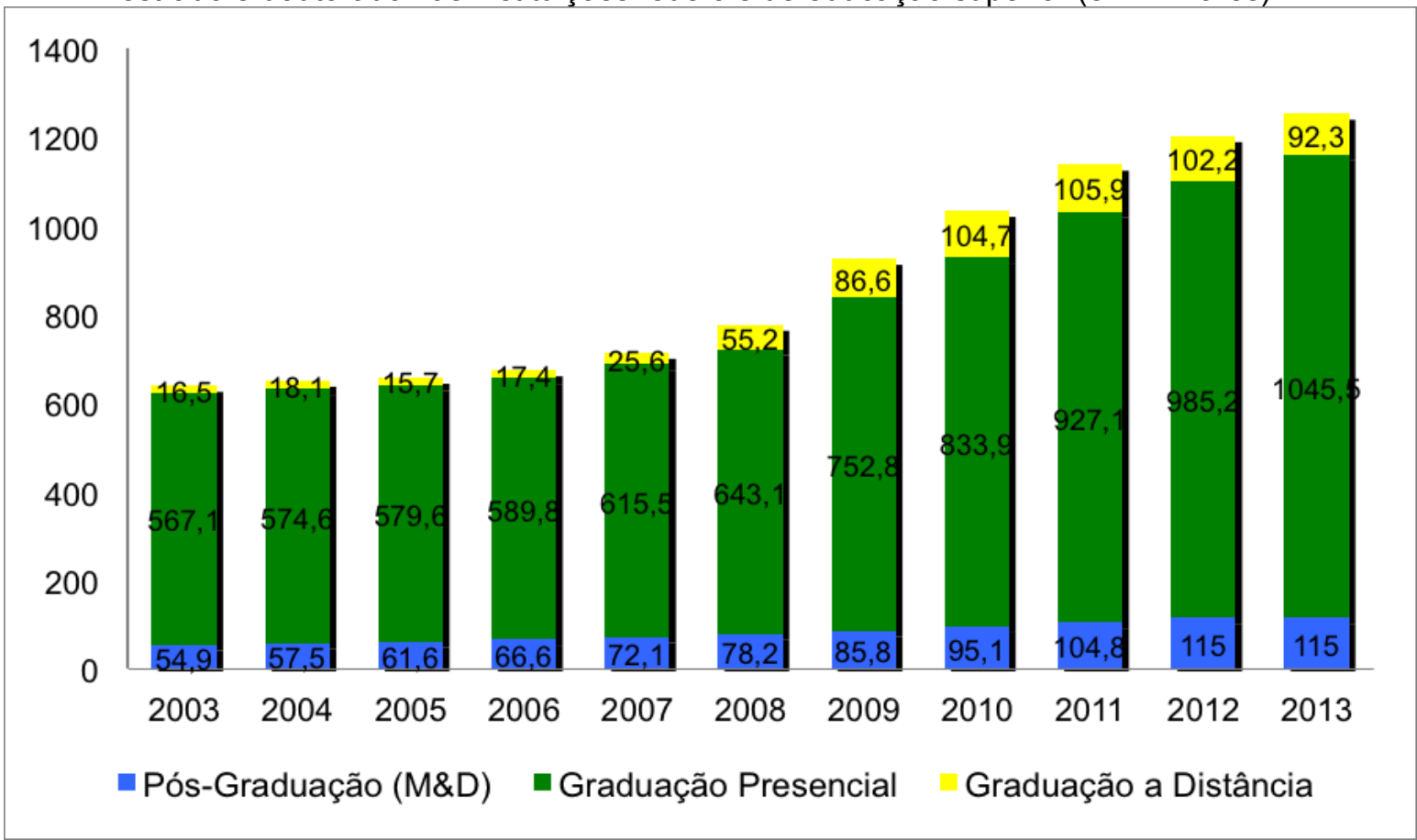

Fonte: INEP/MEC (BRASIL, 2014)

\section{PÓS-GRADUAÇÃO: MESTRADO E DOUTORADO}

No período de 2003 a 2013, verifica-se um aumento de $81,4 \%$ nas matrículas correspondentes a estudantes de mestrado e doutorado nas universidades brasileiras. Na análise dos dados do Censo da Educação Superior dos anos de 2012 e 2013, observou-se que os mesmos coincidem nos anos de 2012 e 2013. Provavelmente, os dados da pós-graduação de 2013 não foram concluídos a tempo de serem atualizados até o momento da divulgação do Censo em nove de setembro de 2014 e foram repetidos. A evolução ano a ano desse indicador, com detalhamento da participação da rede pública e privada, é mostrada na Figura 5. Com relação aos dados apresentados nesta figura, observa-se que enquanto as matrículas nas instituições privadas cresceram 63\% de 2003 a 2013, as matrículas nas 
instituições públicas cresceram $85 \%$ no mesmo período.

Figura 5 - Evolução das matrículas em cursos de mestrado e doutorado nas universidades brasileiras (redes pública, privada e total), em milhares.

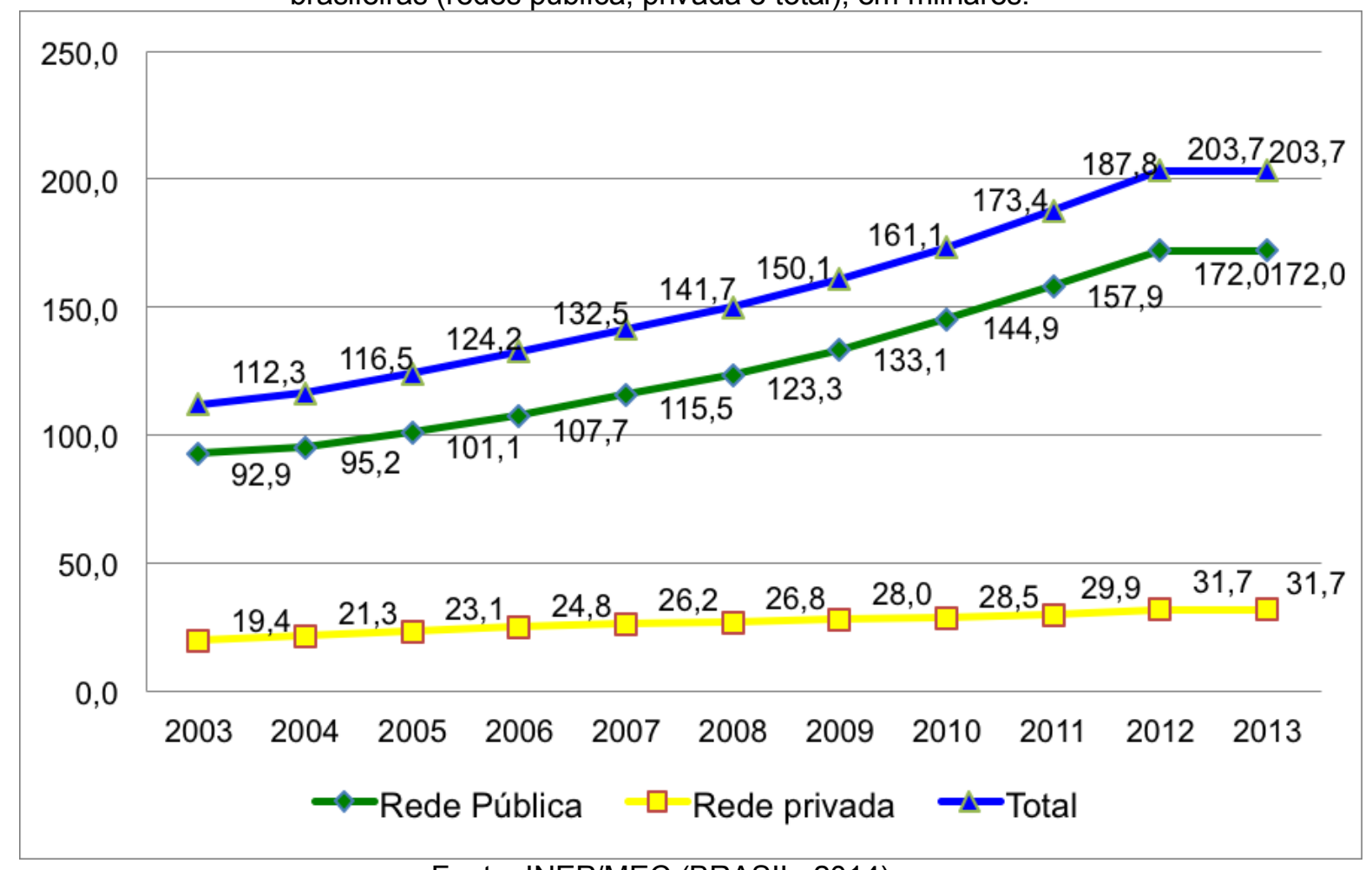

Fonte: INEP/MEC (BRASIL, 2014)

Em contraste com a participação dos setores público $(26 \%)$ e privado (74\%) nas matrículas em cursos de graduação, apresentada no gráfico da esquerda da Figura 2, a relação desses setores nas matrículas de mestrado e doutorado é inversa, como mostra o gráfico da direita nessa mesma figura. No ano de 2012, as matrículas em mestrado e doutorado estão, em sua maioria, no setor público $(84,4 \%)$, ficando a menor parcela para o setor privado $(15,6 \%)$.

Nos últimos anos, o incentivo ao desenvolvimento da pós-graduação foi sensível. Além do crescimento do orçamento da Coordenação de Aperfeiçoamento de Pessoal de Nível Superior (CAPES) para a área, também se verificou um importante aumento no número de bolsas de mestrado e de doutorado, bem como o valor delas. A Figura 6 apresenta a evolução do quantitativo de bolsas de estudos para estudantes de mestrado e doutorado em universidades brasileiras no período de 1995 até 2012. 
Figura 6 - Número de bolsas no país concedidas a estudantes de mestrado e doutorado (em milhares).

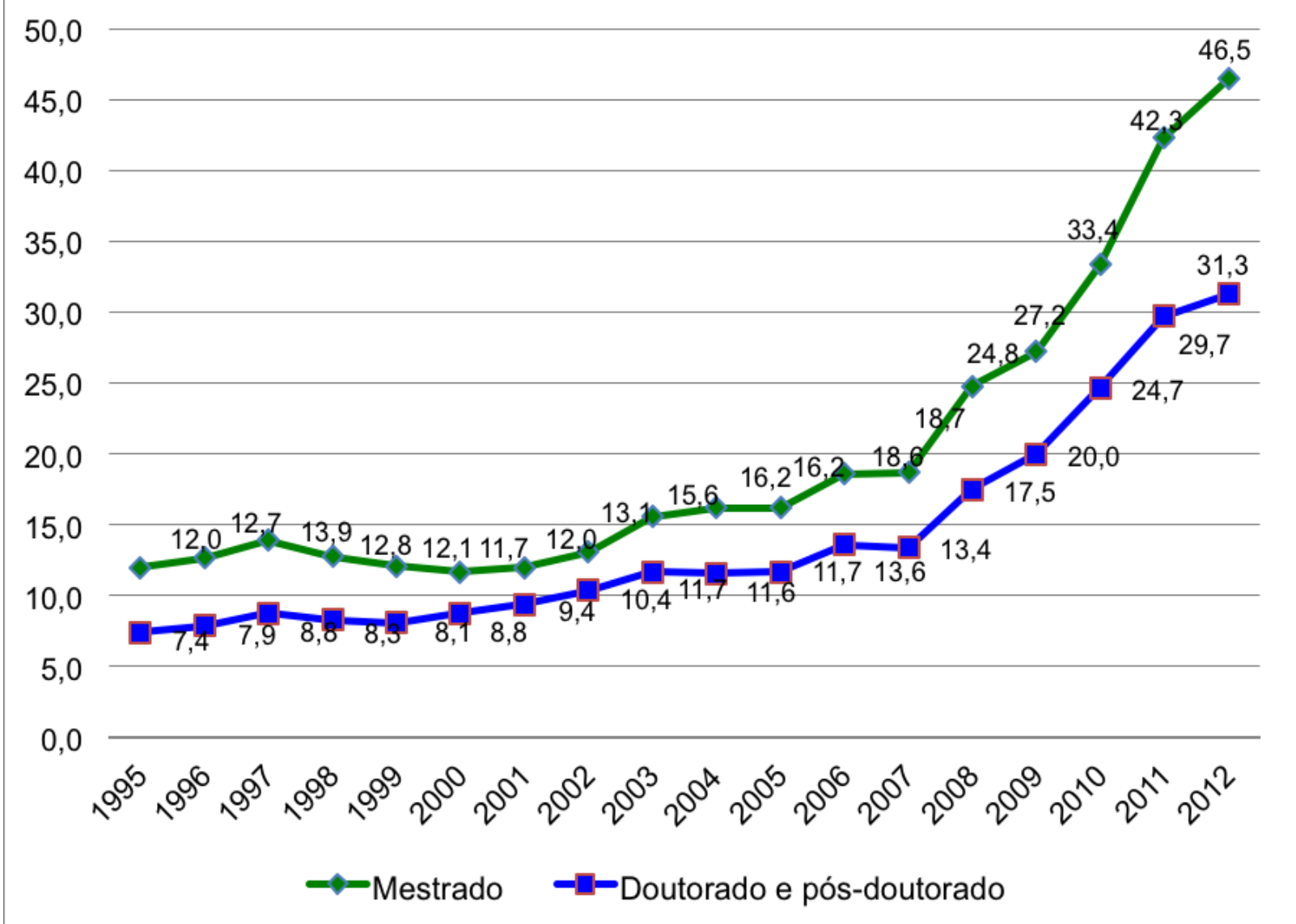

Fonte: Figura elaborada pelo autor a partir de dados da pós-graduação brasileira disponíveis no site da CAPES (geocapes.capes.gov.br)

O gráfico na Figura 7 a seguir mostra a evolução dos valores dessas bolsas no mesmo período. Os valores mensais atuais (novembro de 2014) são $\mathrm{R} \$ 1.500,00$ para mestrado e $\mathrm{R} \$ 2.200,00$ para doutorado. Essas bolsas se destinam ao custeio do bolsista. 
Figura 7 - Evolução dos valores das bolsas no país concedidas a estudantes de mestrado e doutorado

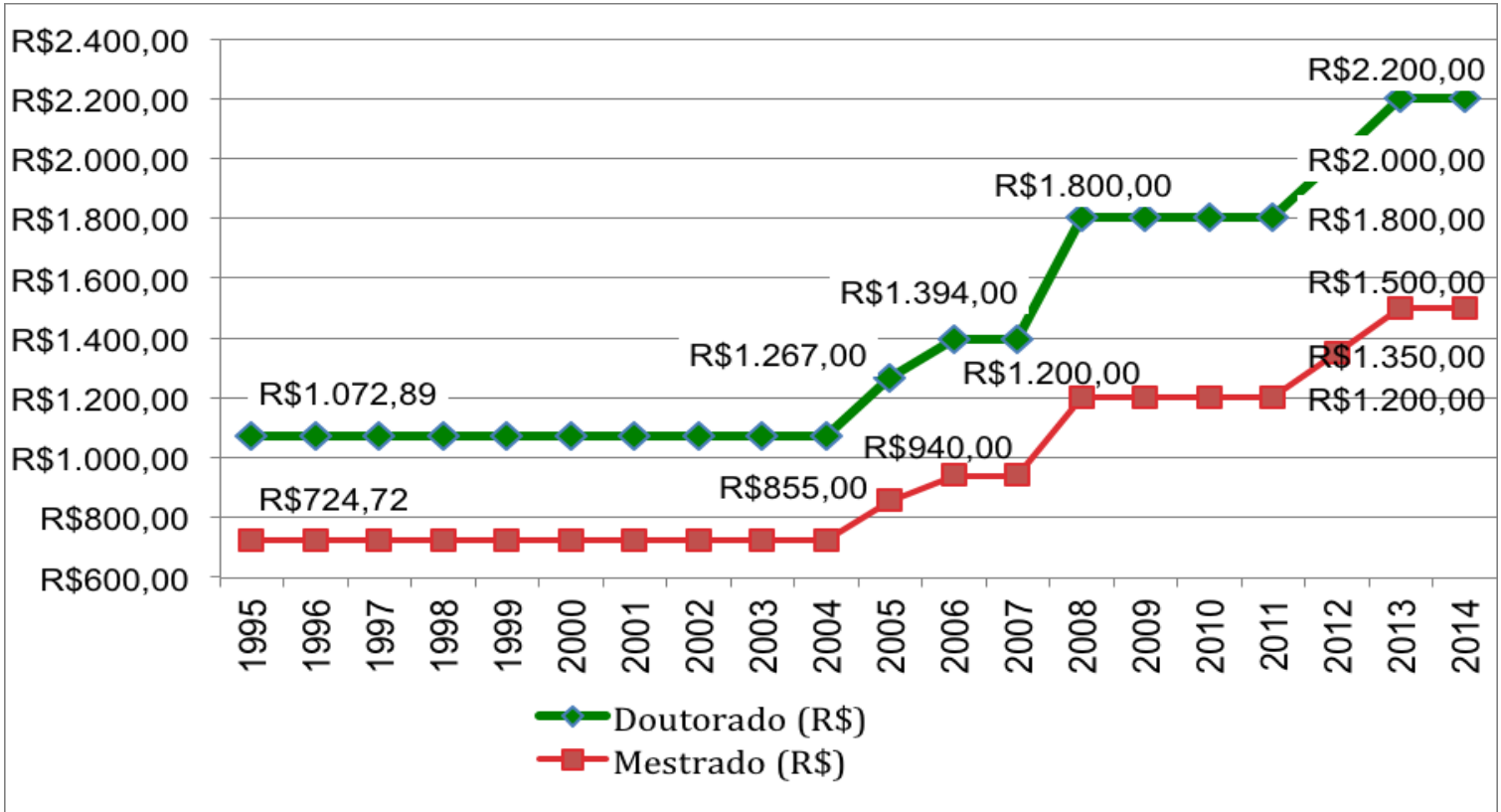

Fonte: Figura elaborada pelo autor a partir de dados da pós-graduação brasileira disponíveis no site da CAPES (geocapes.capes.gov.br)

Um indicador importante a ser acompanhado na área de pesquisa e pósgraduação é a produção acadêmica do sistema de educação superior do Brasil. A Figura 8 mostra a comparação do crescimento da produção acadêmica brasileira em relação a demais países do mundo, baseada no número de artigos publicados em periódicos científicos indexados. Essa comparação tem como referência o ano de 2003 e a fonte é o ISI - Institute for Scientific Information. National Science Indicators, USA. Base Deluxe - SCI (2009), (GUIMARÃES, 2011).

Figura 8 - Comparação do crescimento da produção científica no mundo e no Brasil. 
DOI: http://dx.doi.org/10.7867/1809-0354.2015v10n1p176-202

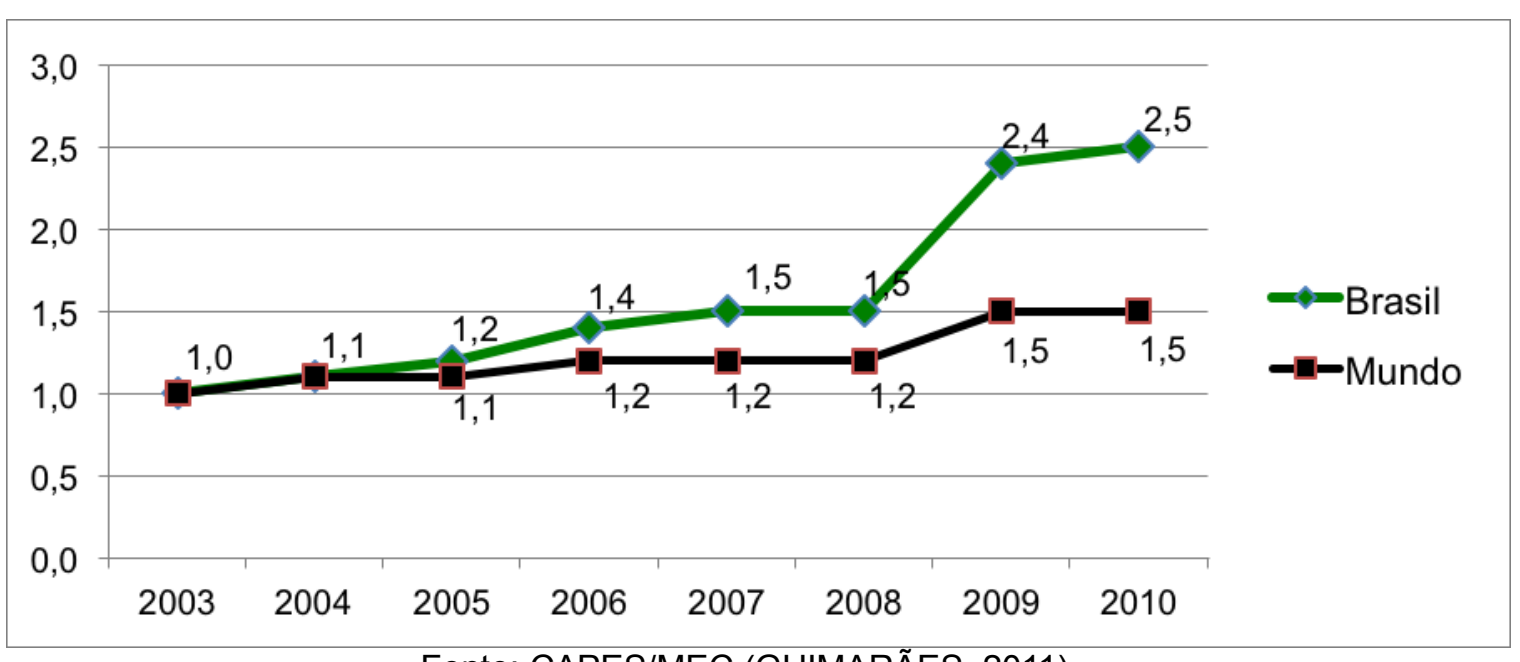

Fonte: CAPES/MEC (GUIMARÃES, 2011)

Os países que mais evoluíram na publicação de artigos em periódicos científicos indexados são apresentados na Tabela 2, a seguir. O Brasil apresenta a segunda maior taxa de crescimento no período de 2003 a 2009, ficando atrás apenas da China.

Tabela 2 - Evolução dos países na publicação em periódicos científicos indexados.

\begin{tabular}{|l|r|r|r|}
\hline \multicolumn{1}{|c|}{ País } & $\mathbf{2 0 0 3}$ & $\mathbf{2 0 0 9}$ & \multicolumn{2}{c|}{$\begin{array}{c}\text { Variação \% } \\
\mathbf{2 0 0 9 / 2 0 0 3}\end{array}$} \\
\hline China & 40.612 & 125.372 & $\mathbf{2 0 9 \%}$ \\
\hline Brasil & $\mathbf{1 4 . 3 1 9}$ & $\mathbf{3 1 . 6 3 9}$ & $\mathbf{1 2 1 \%}$ \\
\hline Turquia & 10.794 & 22.163 & $105 \%$ \\
\hline Índia & 21.518 & 40.905 & $90 \%$ \\
\hline Coréia do Sul & 21.111 & 39.843 & $89 \%$ \\
\hline Taiwan & 13.158 & 23.834 & $81 \%$ \\
\hline Espanha & 27.428 & 44.688 & $63 \%$ \\
\hline Austrália & 25.204 & 39.559 & $57 \%$ \\
\hline Polônia & 12.964 & 19.512 & $51 \%$ \\
\hline Holanda & 22.165 & 30.948 & $40 \%$ \\
\hline
\end{tabular}

Fonte: CAPES/MEC (GUIMARÃES, 2011)

A Tabela 3, na sequência, apresenta os países com maior participação percentual em relação ao total mundial de artigos publicados em periódicos científicos, indexados pela Thomson Reuters (2010). O Brasil aparece na $13^{a}$ posição, o que evidencia um importante avanço. No entanto, se for levado em consideração o fato de que atualmente o Brasil ocupa a $7^{a}$ posição na lista das maiores economias do planeta, tem-se ainda muito que avançar para que a posição da produção científica fique em correspondência com àquela que o 
país tem na participação da economia mundial.

Tabela 3 - Lista dos 20 países com maior participação percentual em relação ao total mundial de publicação em periódicos científicos indexados.

\begin{tabular}{|ll|c|c|}
\hline \multicolumn{1}{|c|}{ País } & $\mathbf{2 0 1 0}$ & $\begin{array}{c}\text { Participação \% em relação ao } \\
\text { mundo }\end{array}$ \\
\hline 1 Estados Unidos & 338.784 & $28,7 \%$ \\
\hline 2 China & 125.372 & $10,6 \%$ \\
\hline 3 Alemanha & 88.420 & $7,5 \%$ \\
\hline 4 & Inglaterra & 80.135 & $6,8 \%$ \\
\hline 5 & Japão & 77.882 & $6,6 \%$ \\
\hline 6 França & 63.601 & $5,4 \%$ \\
\hline 7 Canadá & 54.756 & $4,6 \%$ \\
\hline 8 Itália & 51.453 & $4,4 \%$ \\
\hline 9 Espanha & 44.688 & $3,8 \%$ \\
\hline 10 Índia & 40.905 & $3,5 \%$ \\
\hline 11 Coréia & 39.843 & $3,4 \%$ \\
\hline 12 Austrália & 39.559 & $3,4 \%$ \\
\hline 13 Brasil & 31.639 & $2,7 \%$ \\
\hline 14 Holanda & 30.948 & $2,6 \%$ \\
\hline 15 Rússia & 26.836 & $2,3 \%$ \\
\hline 16 Taiwan & 23.834 & $2,0 \%$ \\
\hline 17 Suíça & 22.239 & $1,9 \%$ \\
\hline 18 Turquia & 22.163 & $1,9 \%$ \\
\hline 19 Suécia & 19.976 & $1,7 \%$ \\
\hline 20 Polônia & 19.512 & $1,7 \%$ \\
\hline Mundo, sem dupla & 1.180 .761 & 100 \\
\hline contagem & & $2011 \%$ \\
\hline
\end{tabular}

Fonte: CAPES/MEC (GUIMARÃES, 2011)

Cumpre salientar a importância do Portal de Periódicos da CAPES, que oferece acesso aos textos completos de artigos selecionados de mais de 21.500 revistas nacionais e estrangeiras, e a 126 bases de dados com resumos de documentos em todas as áreas do conhecimento. O uso do Portal é livre e gratuito para os pesquisadores e estudantes das instituições participantes e é acessível pela internet (http://www.periodicos.capes.gov.br/). No ano de 2013, o Portal atingiu 100,9 milhões de acessos e vai se tornando cada vez mais um valioso instrumento de produtividade para os pesquisadores das instituições de ensino e pesquisa do Brasil.

\section{EXPANSÃO DA REDE FEDERAL DE EDUCAÇÃO SUPERIOR}


A partir de 2004, teve início um conjunto de programas do Governo Federal para promover a interiorização, reestruturação e diversificação da oferta de vagas nas universidades federais brasileiras. Nesse sentido, o primeiro desses programas foi chamado de Expansão Fase I que se iniciou em 2004, cujo principal objetivo foi a oferta de educação universitária no interior do Brasil. Nesse contexto, foram criadas 18 novas universidades federais no período de 2004 a 2014. Planejado em 2007, o REUNI começou a ser executado em 2008 e se estendeu até 2012. A meta projetada do REUNI foi a de ofertar 243,5 mil vagas anuais no ano de 2012, contudo os dados do Censo da Educação Superior deste ano indicaram a oferta de 239,9 mil vagas para estudantes em universidades federais brasileiras em processos seletivos abertos. De fato, algumas universidades federais não cumpriram as metas estabelecidas em seus projetos no REUNI.

A Tabela 4 apresenta um resumo da expansão da rede de universidades federais do Brasil que inclui o programa Expansão Fase I e o REUNI. No período de 2003 a 2014, foram criadas 18 novas universidades federais. Além disso, o número de câmpus e unidades dessas universidades passaram de 148 para 321 e o número de municípios com câmpus de universidades federais passou de 114 para 275 no período em tela.

Tabela 4 - Quadro resumo da expansão da rede de universidades federais (Municípios atendidos por mais de um campus foram contados somente uma vez).

\begin{tabular}{|l|c|c|c|}
\hline & $\mathbf{2 0 0 3}$ & $\mathbf{2 0 1 0}$ & $\mathbf{2 0 1 4}$ \\
\hline $\begin{array}{l}\text { Universidades } \\
\text { Federais }\end{array}$ & 45 & 59 (14 novas) & 63 (4 novas) \\
\hline Câmpus e unidades & 148 & 27 (126 novos) & 321 (47 novos) \\
\hline Municípios atendidos & 114 & 230 & 275 \\
\hline
\end{tabular}

Fonte: Módulo REUNI do Sistema Integrado de Monitoramento Execução e Controle - SIMEC (http://simec.mec.gov.br)

O número de ingressantes em cursos presenciais de graduação nas universidades federais aumentou 127,4\% no período de 2003 a 2013, conforme indicam os dados apresentados no gráfico da Figura 9. É importante ressaltar que após quase dez anos de crescimento ininterrupto, esse indicador tem sua primeira queda, o que evidencia um sinal do esgotamento das políticas públicas do setor. 
Figura 9 - Evolução do número de ingressantes em cursos de graduação presenciais nas universidades federais no período de 2003 a 2013.

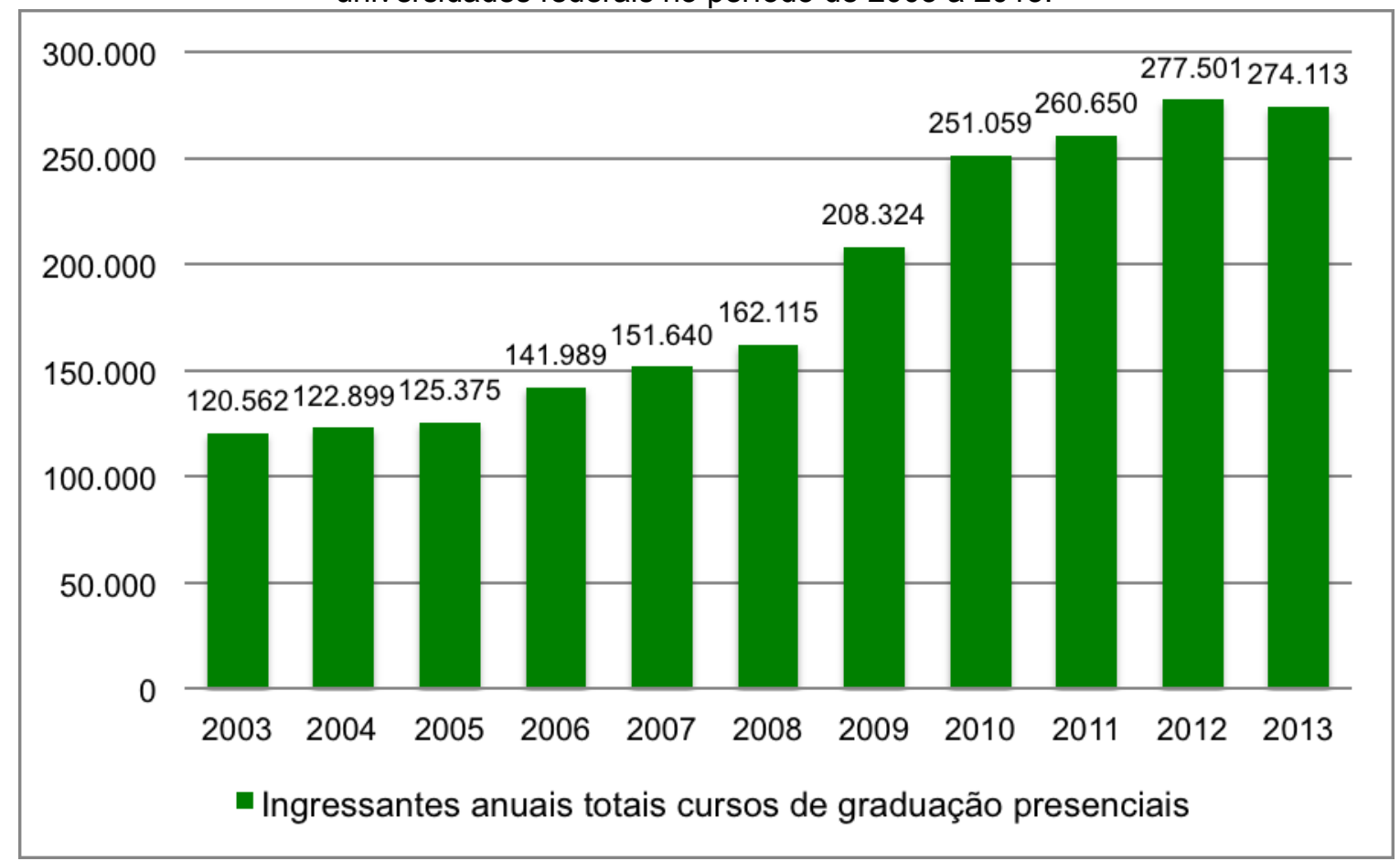

Fonte: Censo da Educação Superior 2013 - INEP/MEC (BRASIL, 2014)

\section{RECURSOS PARA A EDUCAÇÃO SUPERIOR}

Do ponto de vista do financiamento da educação superior pública federal verificou-se, no período de 2003 a 2014, um aumento do orçamento do Ministério da Educação do Brasil, que refletiu diretamente na melhoria do financiamento da rede de universidades federais e do sistema CAPES.

O gráfico apresentado na Figura 10 mostra a evolução do orçamento do MEC no período de 1995 a 2014. Os dados em cor azul representam os valores correntes e os dados em verde representam os valores atualizados monetariamente pelo Índice Nacional de Preços ao Consumidor Amplo do IBGE (IPCA-médio). Constata-se uma certa estagnação no período que vai de 1995 até 2002, e no período posterior percebe-se um incremento sistemático que em 2014 representou um fator de crescimento da ordem de 205,7\% em relação a 2003, em valores atualizados. Os valores foram atualizados monetariamente pelo IPCA-médio relativo ao mês de julho de 2014. 
Figura 10 - Orçamento do Ministério da Educação do Brasil no período de 1995 a 2014 (em R \$ bilhões). Orçamento da administração direta. Inclui FIES e Salário Educação

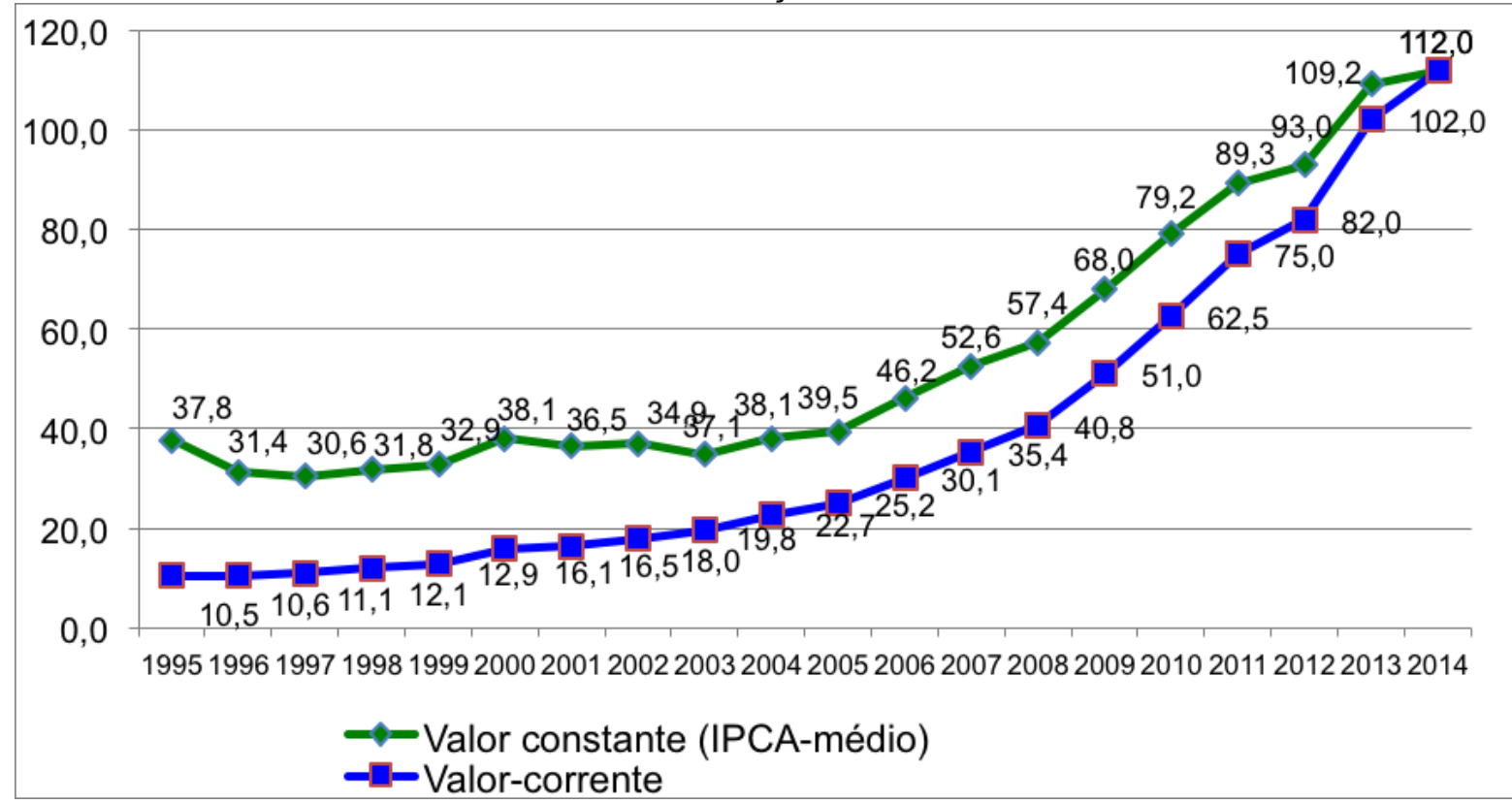

Fonte: Módulo SPO do Sistema Integrado de Monitoramento Execução e Controle - SIMEC (http://simec.mec.gov.br)

Em termos de percentual de investimento público total em educação em relação ao Produto Interno Bruto (PIB), o percentual passou de 4,6\% em 2003 para 5,7\% em 2009, e para 6,4\% em 2012, sobre um PIB 68\% maior. A Figura 11 mostra a evolução do percentual de investimento público em educação como percentual do PIB no período de 2000 a 2011.

A Figura 12 mostra o orçamento global disponibilizado para o conjunto das universidades federais. $\mathrm{O}$ crescimento desse orçamento ocorreu em uma relação proporcional ao crescimento do orçamento do MEC, ou seja, da ordem de $200 \%$, em valores atualizados. O orçamento de cada universidade da rede é definido em função de critérios de qualidade e eficiência acadêmica que levam em consideração o número de estudantes matriculados, os custos de cada curso e as avaliações dos cursos de mestrado e doutorado, entre outros.

Figura 11: Investimento público em educação no período de 2000 a 2011 como percentual do PIB 
Blumenau, v. 10, n.1, p.176-202, jan./abr. 2015

DOI: http://dx.doi.org/10.7867/1809-0354.2015v10n1p176-202

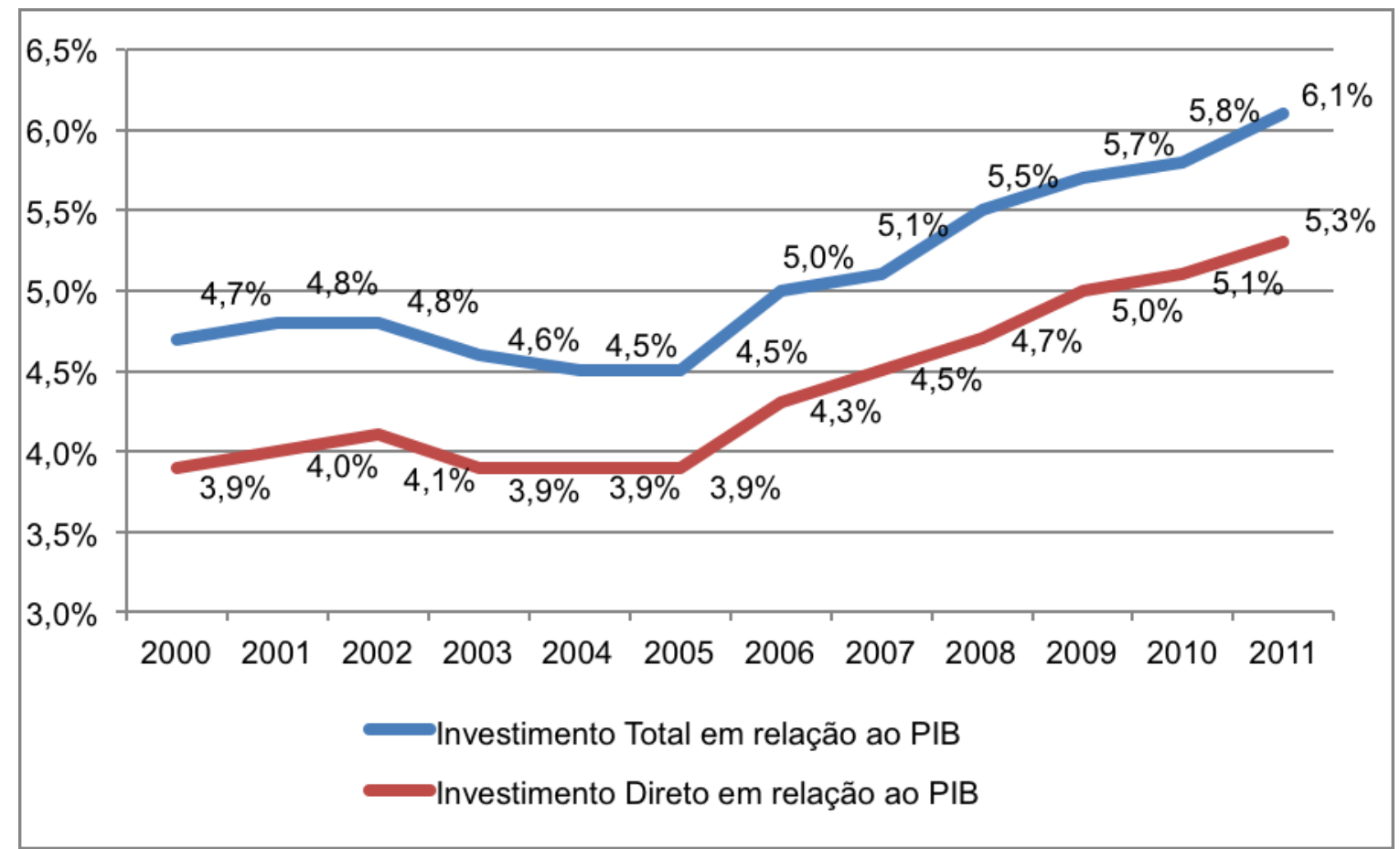

Fonte: INEP/MEC (2014)

Figura 12 - Orçamento das universidades federais do Brasil no período de 2003 a 2013. Inclui hospitais universitários. Não inclui gastos com inativos, precatórios e descentralizações (valores em R $\$$ bilhões)

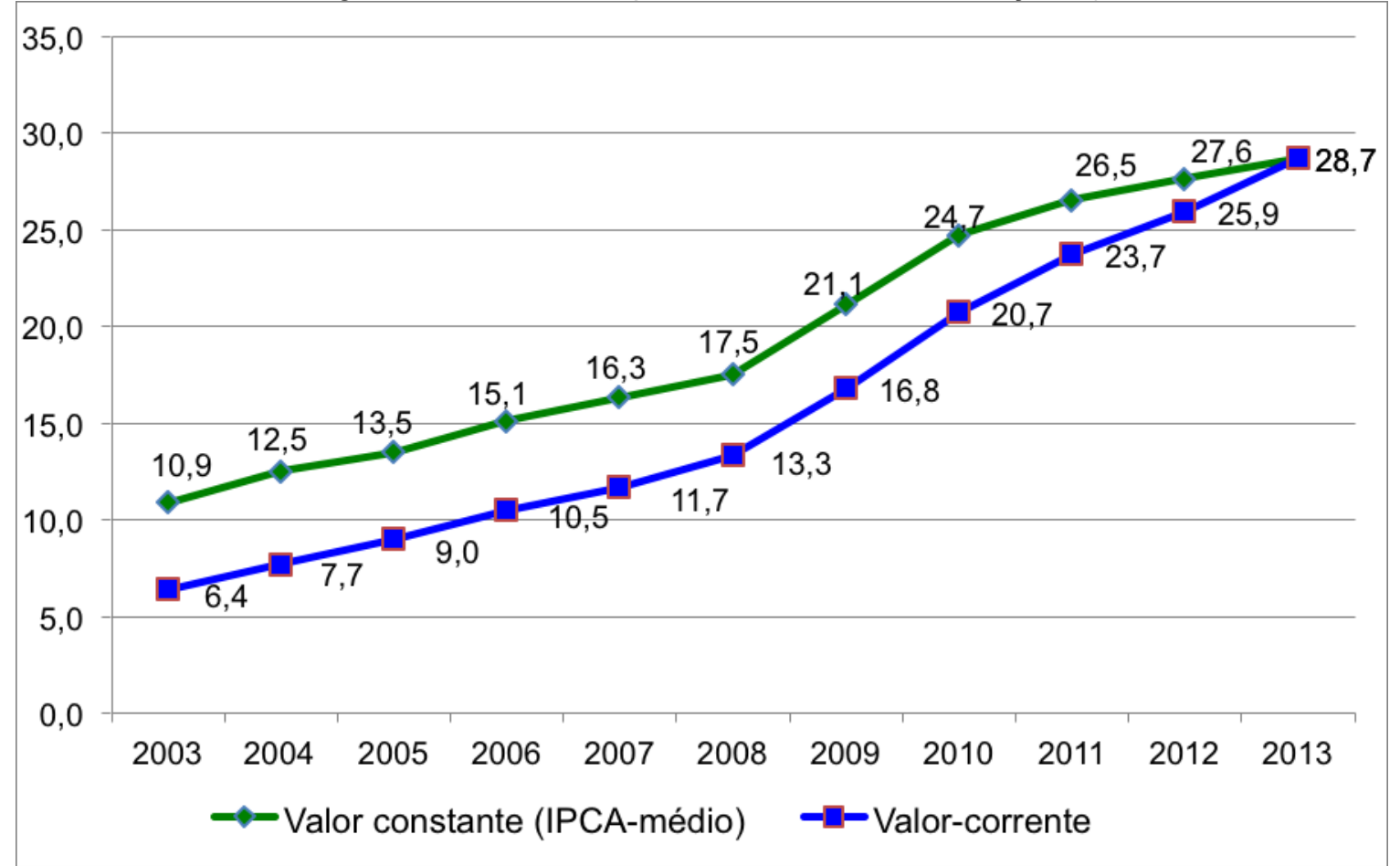

Fonte: Módulo SPO do Sistema Integrado de Monitoramento Execução e Controle - SIMEC

(http://simec.mec.gov.br)

A Figura 13 mostra a evolução do orçamento da CAPES no período de 
1995 a 2011. Observa-se que, proporcionalmente ao orçamento do MEC, o orçamento da CAPES aumentou numa relação ainda maior, neste caso, um avanço de cerca de $300 \%$. Além da avaliação e o fomento da pós-graduação, a CAPES é responsável pelo sistema de formação de professores para a educação básica e pelo Portal de Periódicos.

Figura 13 - Orçamento da CAPES/Brasil no período de 1995 a 2010 (em R\$ bilhões)

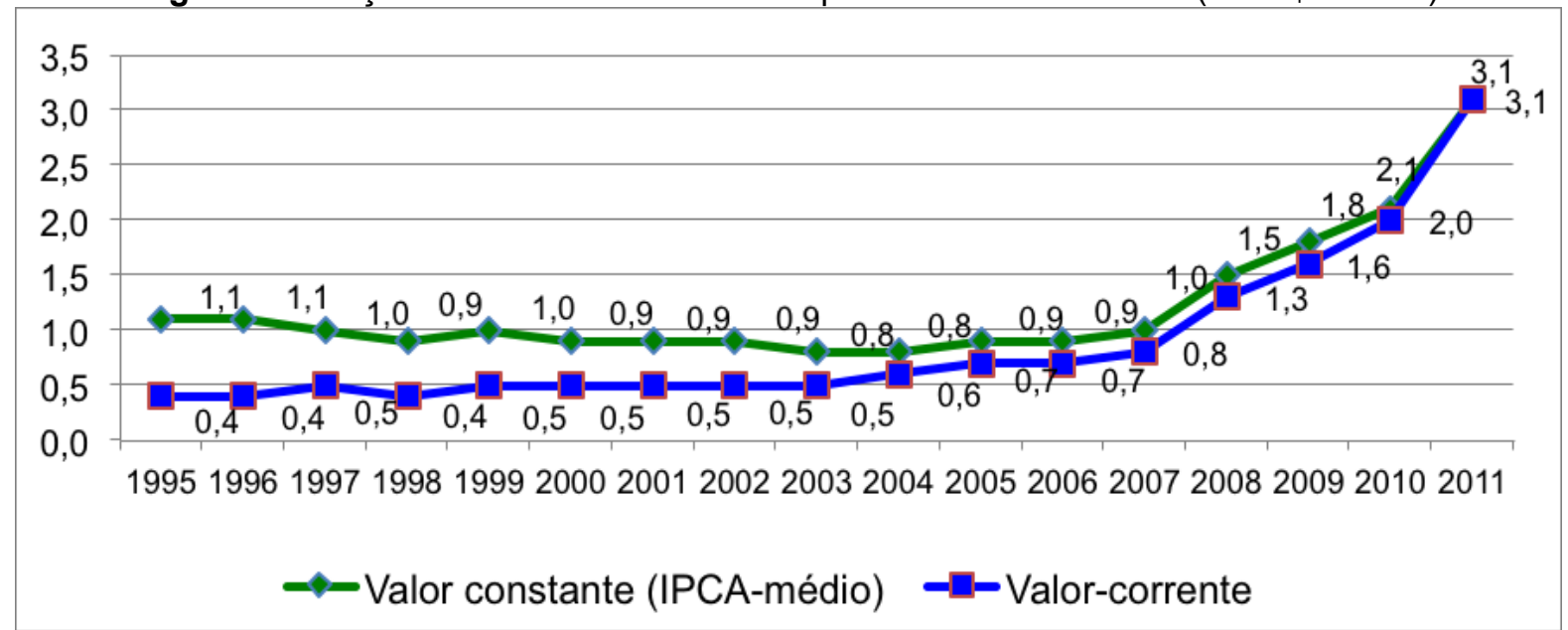

Fonte: Módulo PDE do Sistema Integrado de Monitoramento Execução e Controle - SIMEC (http://simec.mec.gov.br)

\section{ACESSO E PERMANÊNCIA NA EDUCAÇÃO SUPERIOR}

Em 1999, cria-se o Fundo de Financiamento ao Estudante do Ensino Superior (FIES), programa do Ministério da Educação destinado a financiar a graduação na educação superior de estudantes matriculados em instituições privadas. Podem recorrer ao financiamento os estudantes matriculados em cursos superiores com avaliação positiva nos processos conduzidos pelo MEC.

Concomitantemente ao processo de expansão da rede de universidades federais, no período de 2003 a 2014, para interiorizar e ampliar a oferta de vagas na educação superior, o MEC iniciou o Programa Universidade para Todos (ProUni) endereçado às IES privadas para favorecer o acesso dos jovens àquelas instituições. O ProUni foi criado em 2005 pela Lei $n^{\circ}$ 11.096/2005, com o intuito de conceder bolsas de estudos integrais e parciais a estudantes de cursos de graduação, em instituições privadas de educação 
superior. As instituições que aderem ao programa recebem isenção de tributos. O ProUni é dirigido aos estudantes egressos do ensino médio da rede pública ou da rede particular na condição de bolsistas integrais, com renda per capita familiar máxima de três salários mínimos. O sistema de seleção do Programa é informatizado e os candidatos são selecionados pelas notas obtidas no Exame Nacional do Ensino Médio (ENEM). Nos últimos anos, o número médio de bolsas ofertadas para estudantes tem sido da ordem de 250 mil bolsas por ano e, desde a sua criação, o ProUni já beneficiou mais de 1,2 milhão de estudantes. A Figura 14, a seguir, mostra a evolução, ao longo dos anos, do número de bolsas ofertadas neste programa. Além da isenção da mensalidade, o ProUni, em alguns casos, oferta aos estudantes uma bolsa a título de assistência estudantil. $\mathrm{O}$ valor da bolsa é equivalente ao de uma bolsa de iniciação científica (CAPES/CNPq) que atualmente tem um valor de $\mathrm{R} \$ 400,00$ mensais e é destinada ao custeio do estudante.

Figura 14 - Bolsas ofertadas pelo Programa Universidade para Todos (ProUni), em milhares

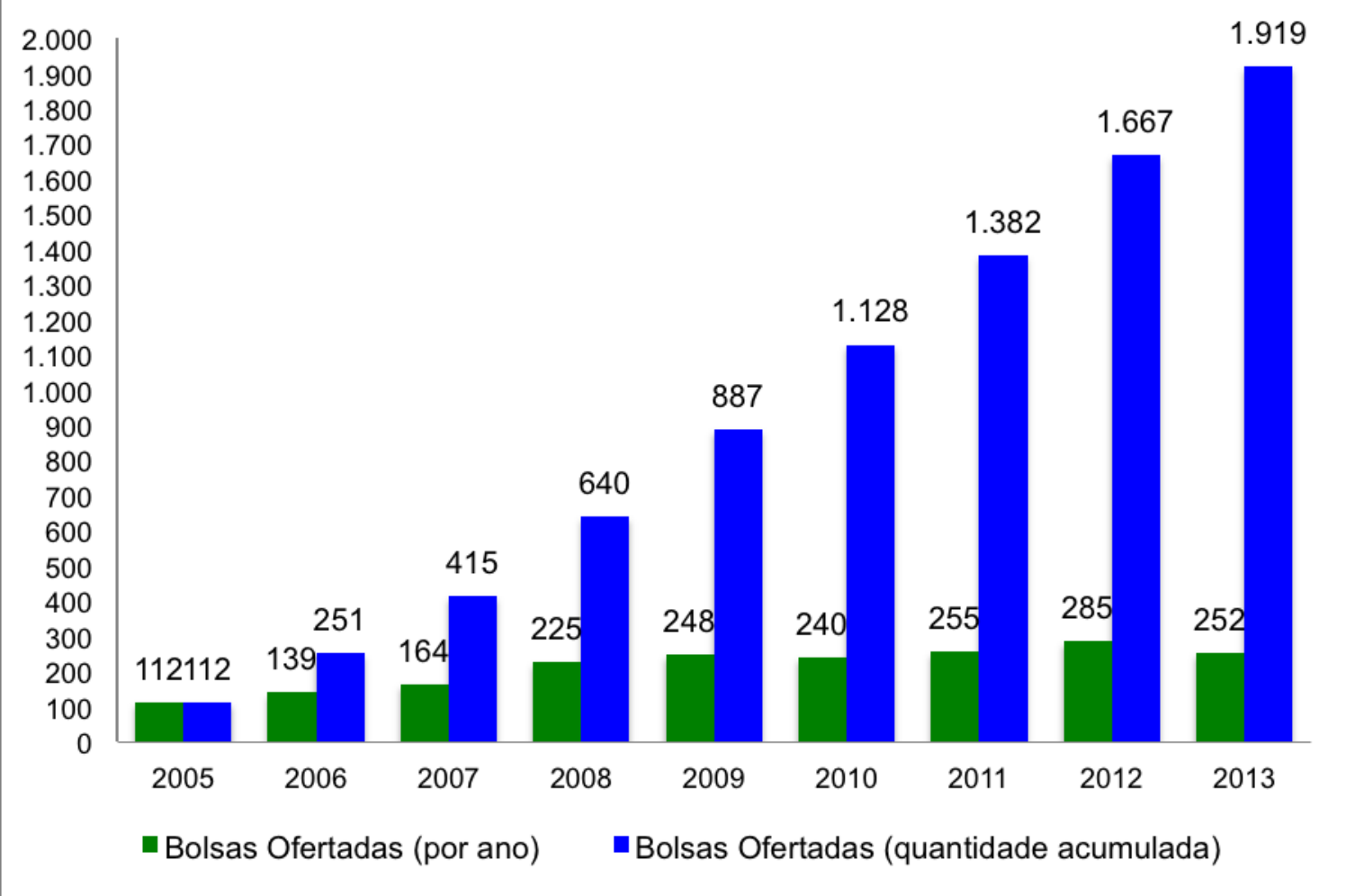

Fonte: Módulo PDE do Sistema Integrado de Monitoramento Execução e Controle - SIMEC (http://simec.mec.gov.br) 
Com relação às políticas públicas endereçadas ao acesso dos estudantes à educação superior, destaca-se o Exame Nacional do Ensino Médio (ENEM). Este exame, de caráter não obrigatório para os estudantes, foi criado em 1998 e reformulado em 2009. Inicialmente, avaliava o desenvolvimento de competências e habilidades gerais dos estudantes concluintes do ensino médio com o objetivo central de avaliar este nível de ensino. A partir do ano de 2005, o ENEM começou a ser utilizado com fins de seleção para os estudantes do ProUni. Em 2009, passou por um processo de reestruturação para torná-lo um exame que, além de avaliar o desempenho no ensino médio, também pudesse ser utilizado com fins classificatórios em processos seletivos para acesso às universidades públicas, as quais se caracterizam pelo alto índice de seletividade em seus concursos vestibulares tradicionais. Nesse sentido, foi desenvolvido pelo MEC o Sistema de Seleção Unificada (SiSU) para selecionar os candidatos às vagas das instituições públicas de ensino superior que utilizam a nota do ENEM como única fase de seu processo seletivo. O SiSU teve seu início no ano de 2010 e tem se mostrado um valioso instrumento para a democratização do acesso às universidades públicas brasileiras. Em 2014, mais da metade das vagas ofertadas pelas universidades federais brasileiras tiveram o processo seletivo por meio do ENEM/SiSU. Nesse mesmo ano, o número de candidatos do ENEM foi 8.721.946. A Figura 15 mostra a evolução do número de inscritos no ENEM no período de 1998 até 2014.

Figura 15 - Número de inscritos no ENEM de 1998 até 2014. 
DOI: http://dx.doi.org/10.7867/1809-0354.2015v10n1p176-202

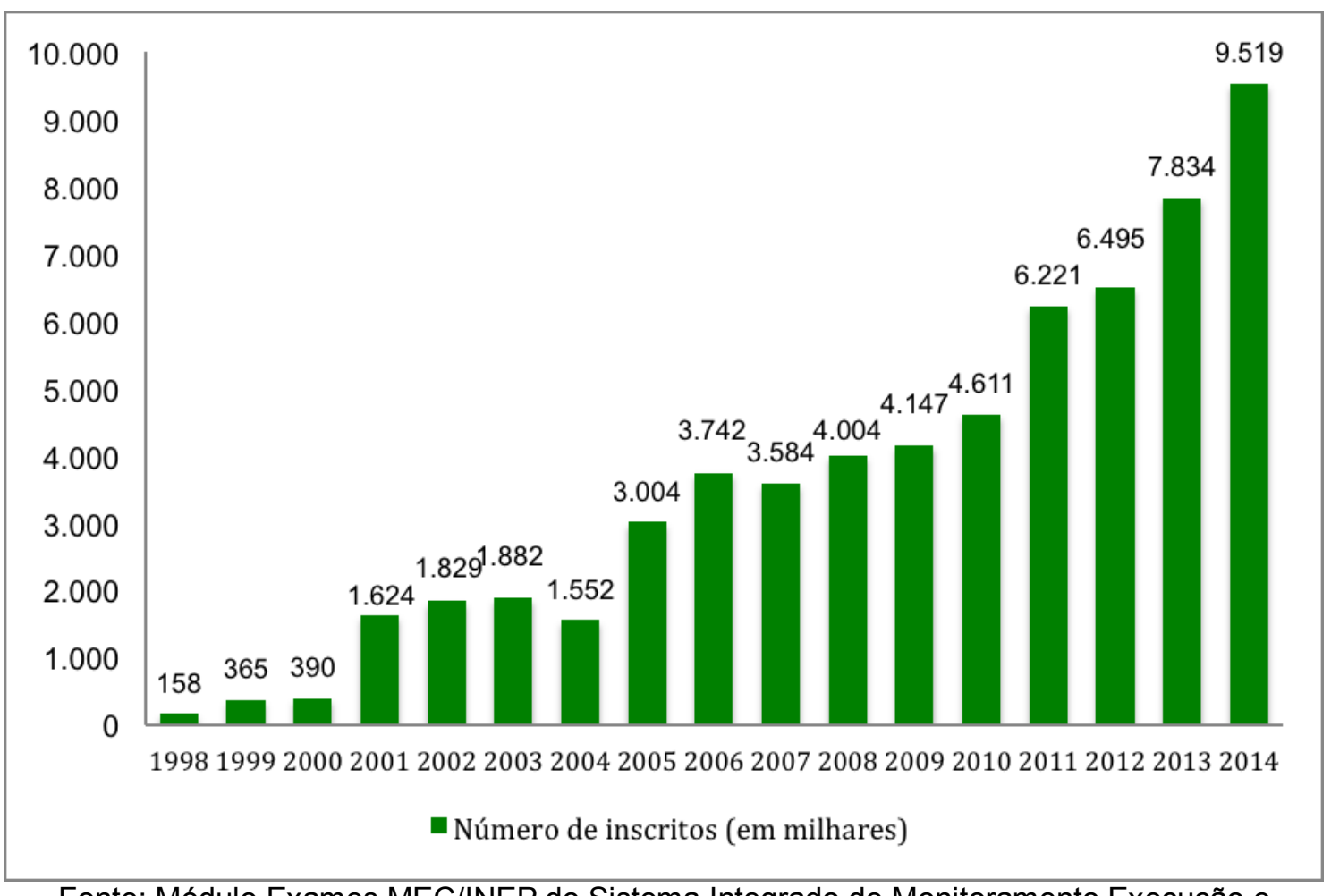

Fonte: Módulo Exames MEC/INEP do Sistema Integrado de Monitoramento Execução e Controle - SIMEC (http://simec.mec.gov.br)

Em decorrência do aumento da democratização do acesso às universidades federais, a partir dos programas de expansão iniciados em 2004, se criou, no ano de 2008, o Programa Nacional de Assistência Estudantil (PNAES), que apoia a permanência dos estudantes de baixa renda matriculados em cursos de graduação presenciais nas universidades federais brasileiras. O objetivo é viabilizar a igualdade de oportunidades entre todos os estudantes e contribuir para a melhoria do desempenho acadêmico. Neste programa, o MEC repassa recursos para as universidades federais para que elas desenvolvam ações de assistência a: moradia estudantil, alimentação, transporte, saúde, inclusão digital, cultura, esporte, creche e apoio pedagógico. A Figura 16 mostra os valores anuais que foram repassados às universidades federais desde o início do programa em milhões de Reais. Para o ano de 2014, o valor previsto foi da ordem de $\mathrm{R} \$ 701,4$ milhões. 
Figura 16 - PNAES: Valores repassados às universidades federais para aplicação em assistência estudantil (em R $\$$ milhões)

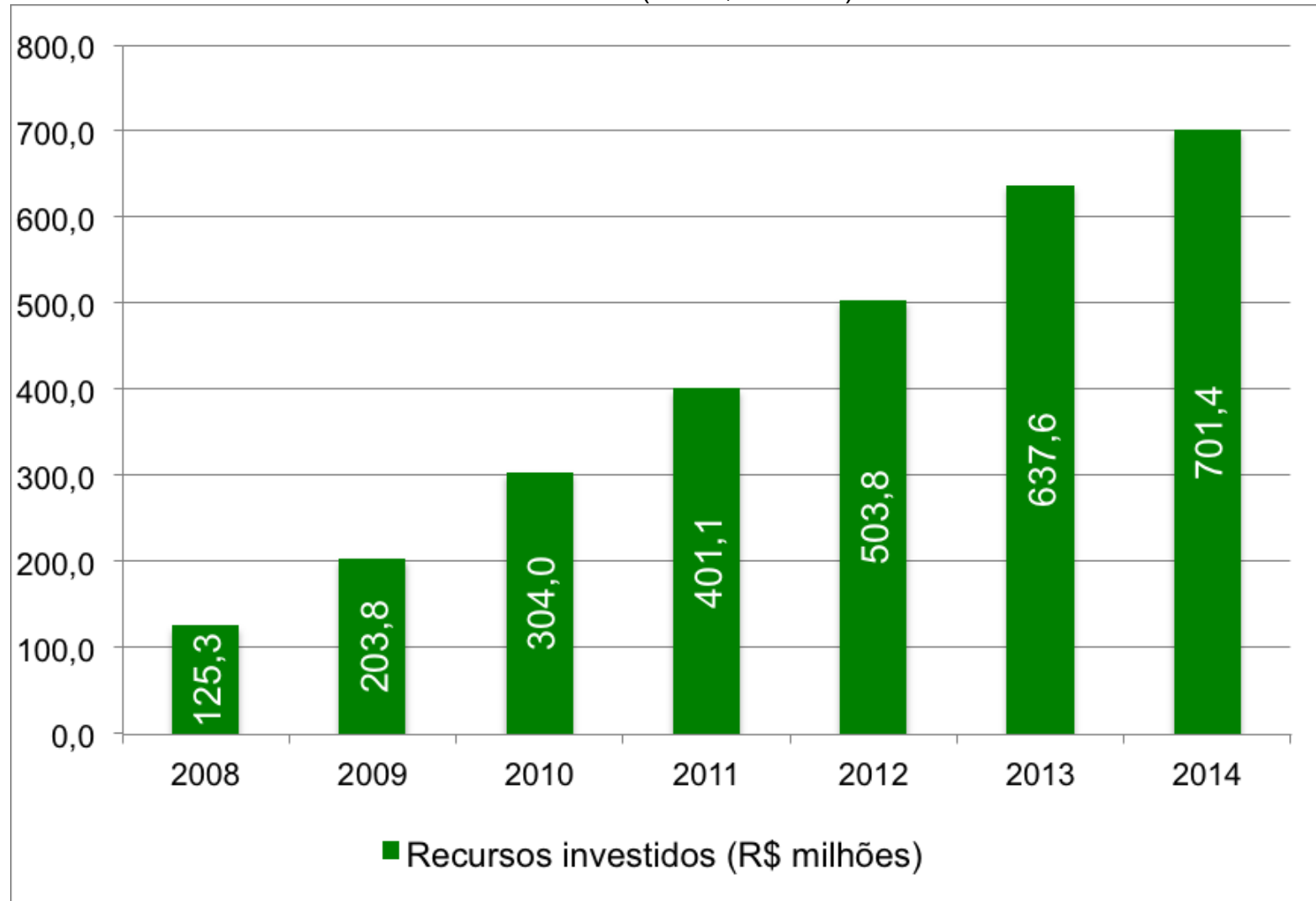

Fonte: Módulo PDE do Sistema Integrado de Monitoramento Execução e Controle - SIMEC (http://simec.mec.gov.br)

A fim de contemplar também os estudantes das universidades estaduais, no ano de 2011, o MEC deu início ao Programa Nacional de Assistência Estudantil para as Instituições de Educação Superior Públicas Estaduais (PNAEST), com o intuito de atender estudantes matriculados em cursos de graduação presencial dessas instituições. A política de distribuição de recursos do PNAEST é baseada no ENEM/SiSU e o total de recursos transferidos para as universidades estaduais é proporcional ao número de vagas oferecidas por estas instituições para serem preenchidas por meio deste sistema. A regra é a seguinte: até 200 vagas ofertadas por meio do SiSU, a universidade recebe um aporte de até $R \$ 150$ mil; entre 201 e 1 mil vagas, até $R \$ 750$ mil; e acima de mil vagas até $R \$ 1,5$ milhão.

\section{REGULAÇÃO, AVALIAÇÃO E SUPERVISÃO DA EDUCAÇÃO SUPERIOR}


Em 2004, foi sancionada a Lei $n^{\circ} 10.861$ que institui o Sistema Nacional de Avaliação da Educação Superior - SINAES. A partir desse momento, se implementou um conjunto de medidas para estabelecer as bases de um sistema de regulação, avaliação e supervisão da educação superior no Brasil. Esse sistema inclui a Portaria MEC $n^{\circ} 40$ de 2007, que é consolidada na Portaria MEC n 40 de 2010.

No contexto do SINAES, entre os anos 2004 e 2012, foram realizadas 24.945 avaliações in loco de cursos de graduação. A Figura 17 mostra o número de avaliações realizadas a cada ano desde a criação do SINAES em 2004. As avaliações dos cursos de graduação, junto com as avaliações institucionais, as avaliações dos programas de mestrado e doutorado e outros insumos relativos ao acompanhamento da qualidade da educação superior estão sendo utilizadas de forma sistêmica em todos os aspectos do sistema de regulação, avaliação e supervisão da educação superior no Brasil.

Figura 17 - Número de avaliações de cursos de graduação in loco no período 2004 a 2012.

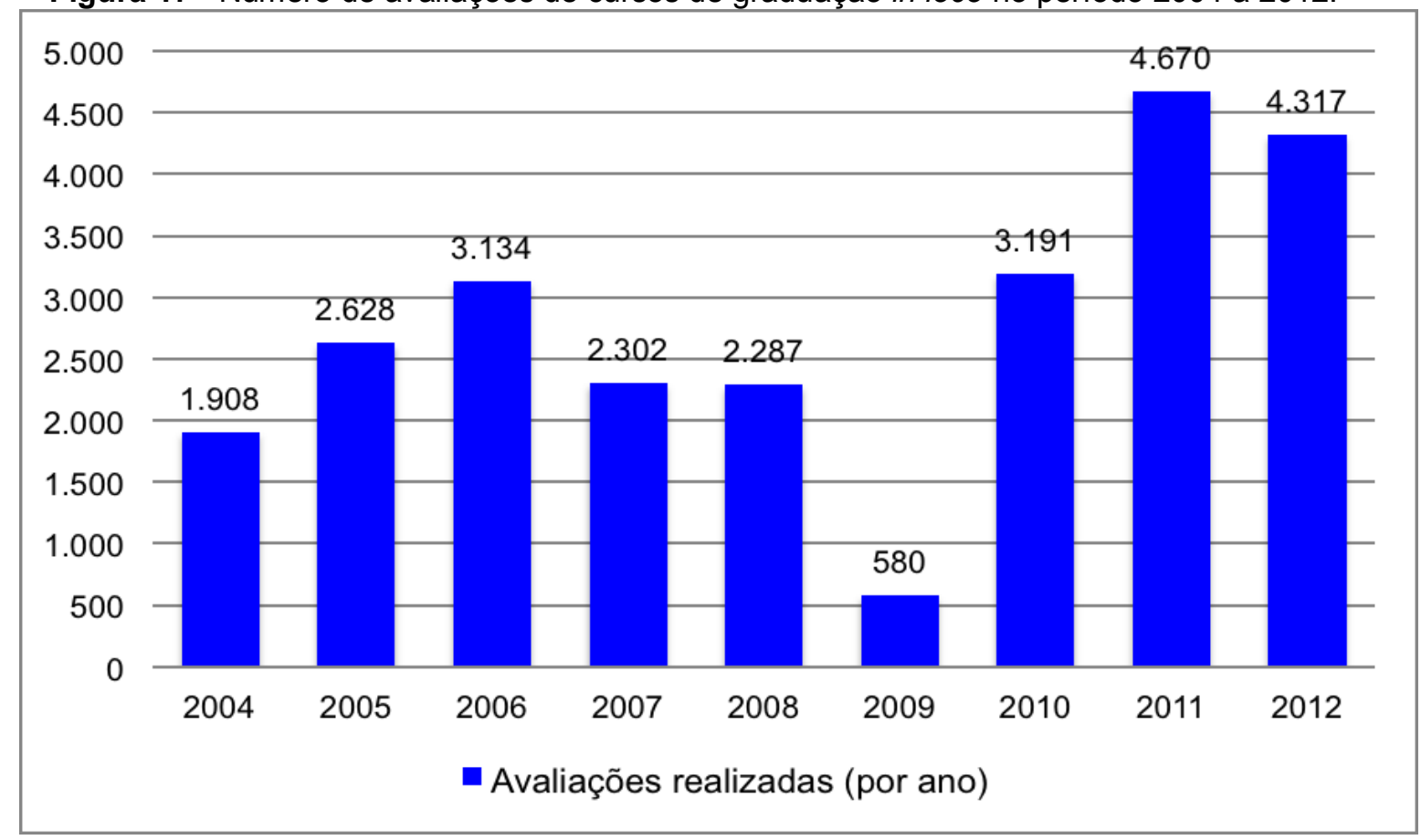

Fonte: Módulo PDE do Sistema Integrado de Monitoramento Execução e Controle - SIMEC (http://simec.mec.gov.br) 


\section{TAXAS DE ESCOLARIZAÇÃO LÍQUIDA E BRUTA DA EDUCAÇÃO SUPERIOR NA FAIXA DE 18 A 24 ANOS}

O primeiro Plano Nacional de Educação que teve vigência de 2001 a 2010, estabelecido pela Lei $n^{\circ} 10.172$, de 9 de janeiro de 2001, propunha metas de cobertura da educação superior que deveriam atingir uma taxa líquida de escolarização, na faixa etária de 18 a 24 anos, de $30 \%$ até o ano 2010. Mesmo com a implementação de programas para ampliação do acesso à educação superior, como o ProUni, a Expansão Fase I, o REUNI, o SISu e a UAB, essa meta não foi alcançada e o valor obtido foi de $14,8 \%$, menos da metade da meta estabelecida. A Figura 18 mostra a evolução desses indicadores no período de 2001 a 2012.

Deve-se levar em consideração a dureza do indicador taxa de escolarização líquida na faixa de 18 a 24 anos, que por definição considera apenas os estudantes matriculados na educação superior no ano em análise, excluindo os estudantes nesta faixa etária que já concluíram cursos de graduação. Esses números não são desprezíveis. Por exemplo, a partir dos dados divulgados pelo MEC relativos ao ano de 2011, se fossem incluídos no indicador os estudantes que concluíram seus cursos, o valor da taxa líquida de escolarização passaria de $14,9 \%$, como se pode verificar no gráfico da Figura 17 , para o valor de $17,8 \%$.

Figura 18 - Taxas de Escolarização Líquida e Bruta na Educação Superior (faixa etária de 18 a 24 anos) expressa em percentuais 


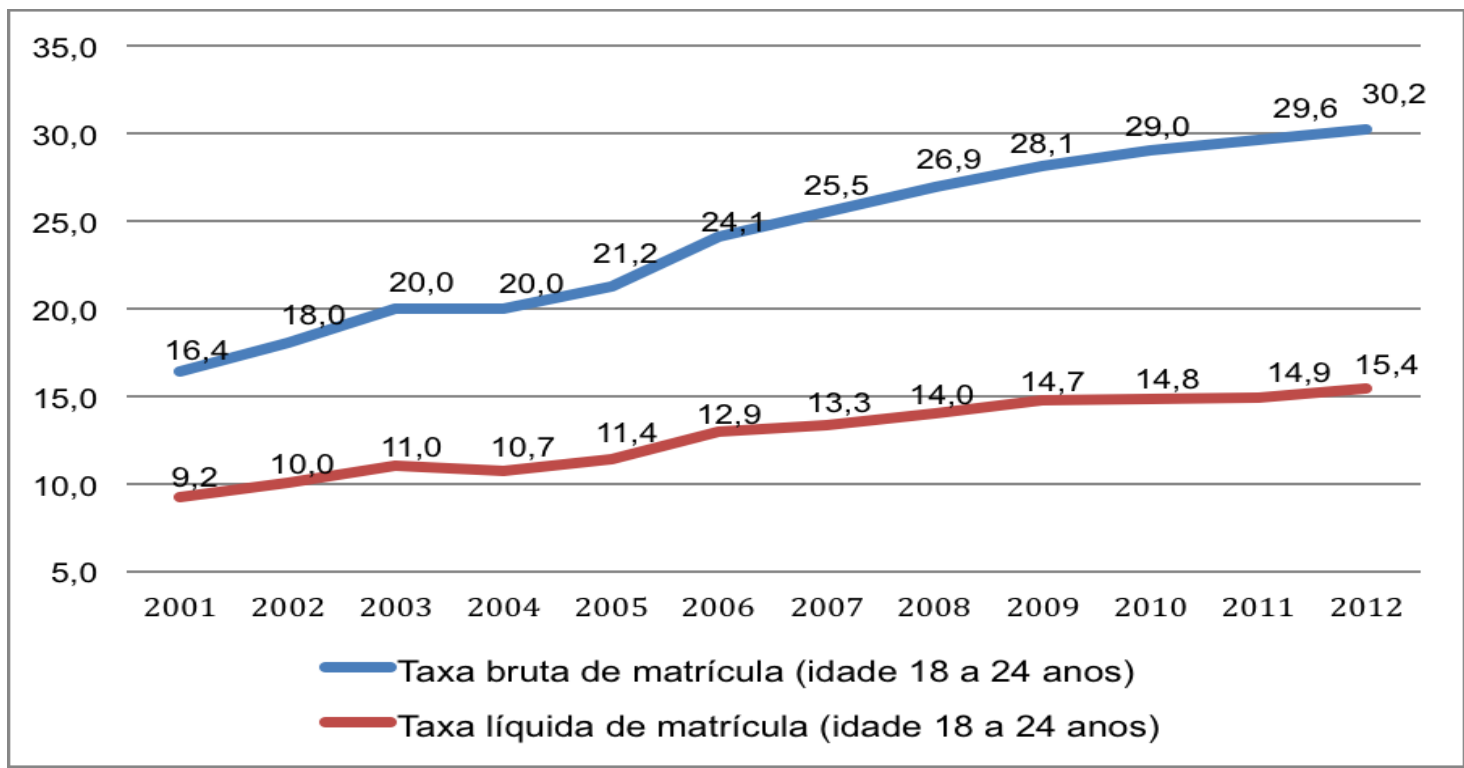

Fonte: Módulo Painel de Controle do Sistema Integrado de Monitoramento Execução e Controle - SIMEC (http://simec.mec.gov.br)

Por outro lado, a Lei no 13.005 de 25 junho de 2014, que institui o Plano Nacional de Educação (PNE) do período 2014 a 2023, estabelece por meio de sua Meta número 12, que seja elevada a taxa bruta de matrícula na educação superior para $50 \%$ e a taxa líquida para $33 \%$ da população de jovens de 18 a 24 anos no fim da vigência, assegurada a qualidade da oferta e expansão para, pelo menos, $40 \%$ das novas matrículas no segmento público.

\section{CONCLUSÃO}

Houve um significativo aumento no número de matrículas na educação superior no período 2003 a 2013, contribuindo para um maior acesso dos jovens à educação superior, numa política deliberada do Governo Federal que se concretiza, principalmente, através das iniciativas: Programa Universidade para Todos (ProUni), Programa de Reestruturação e Expansão das Universidades Federais (REUNI), Programa Universidade Aberta do Brasil (UAB) e a expansão da rede federal de educação profissional e tecnológica.

As universidades tiveram uma ampliação e modernização de sua infraestrutura, com investimentos significativos na edificação de salas de aula e laboratórios. Muitas universidades são, hoje, verdadeiros canteiros de obras. 
Em termos de estudantes, a rede de universidades federais dobrou de tamanho no período de 2003 a 2013. Tornou-se mais democrática e mais próxima da sociedade brasileira. Entretanto, mesmo com todo o crescimento das universidades públicas e das instituições privadas no período em tela, o conjunto de IES do Brasil ainda está longe de alcançar a meta de cobertura de $30 \%$ de taxa de escolarização líquida para a faixa etária de 18 a 24 anos, prevista no PNE de 2001 a 2010. A taxa líquida alcançada em 2010 ficou próxima de $14,8 \%$, longe da meta prevista.

A Meta 12 do novo PNE para o período de 2014 a 2023 prevê a meta de cobertura para a faixa de 18 a 24 anos de $33 \%$ de taxa de escolarização líquida e $50 \%$ de taxa de escolarização bruta. O desenvolvimento e fortalecimento da educação superior pública brasileira precisam ser continuados de maneira sustentável para que se alcance as metas propostas. O documento final da Conferência Nacional de Educação (BRASIL, 2010) indica que o Brasil precisa estabelecer, até 2020, uma relação de matrículas na educação superior de $40 \%$ para o setor privado e de $60 \%$ para o setor público, contra os atuais $76 \%$ do setor privado e $24 \%$ do setor público.

Os dados globais de concluintes em todo o sistema de educação superior (Figura 3) e os números de ingressantes nas universidades federais (Figura 9) apontam para um esgotamento das políticas que foram endereçadas ao setor na última década. Deve-se ressaltar que o cumprimento da Meta 12 do PNE 2014 a 2023 requer a definição de políticas públicas arrojadas. Contudo, até o momento, não se iniciou qualquer ação para viabilizar o atendimento dessa Meta.

\section{MURILO SILVA DE CAMARGO}

Doutor em Engenharia. Professor associado da Universidade de Brasília UnB. Foi Pró-reitor de Ensino de Graduação da UnB e Coordenador-Geral de Expansão e Gestão das IFES, da Secretaria de Educação Superior do MEC.

\section{REFERÊNCIAS}

BRASIL. Ministério da Educação. Censo da Educação Superior 2013. 
INEP/MEC. Brasília, 2014. Disponível em:

<http://download.inep.gov.br/educacao_superior/censo_superior/documentos/2 014/principais_resultados_censo_2013.xls>. Acesso em: 10 set. 2014.

BRASIL. Ministério da Educação. Diretrizes Gerais do Programa REUNI. MEC/SESu. Brasília, 2007. Disponível em:

$<$ http://portal.mec.gov.br/sesu/arquivos/pdf/diretrizesreuni.pdf>. Acesso em: 30 nov. 2011.

BRASIL. Ministério da Educação. Conferência Nacional de Educação CONAE. MEC. Brasília, 2010. Disponível em:

<http://conae.mec.gov.br/images/stories/pdf/pdf/documetos/documento_final_sl. pdf>. Acesso em: 30 nov. 2011.

CUNHA, L. A. C. R. A universidade reformada: o golpe de 1964 e a modernização do ensino superior. São Paulo, Editora UNESP, 2007, 248 p.

FIGUEIREDO, G. V. R. Educação Universal e de Qualidade: Um Projeto para o Brasil. São Paulo, 2010. Disponível em: <http://proifes.org.br/wpcontent/uploads/2010/06/Artigo-PNE-Gil-08-fev-10.pdf>. Acesso em: 30 nov. 2011.

GUIMARÃES, J. Plano Nacional de Pós-Graduação - PNPG 2011-2020.

CAPES/MEC. Brasilia, 2011. p. 25. Disponível em:

<http://portal.mec.gov.br/index.php?option=com_docman\&task=doc_download\& gid=8759\&ltemid=>. Acesso em: 07 mai. 2015.

RIGOTTO, M. E.; SOUZA, N. J., Evolução da Educação no Brasil, 1970-2003. Análise. Porto Alegre v. 16, n. 2, pp. 351-375. ago/dez 2005. Disponível em <http://revistaseletronicas.pucrs.br/ojs/index.php/face/article/view/278/227>. Acesso em: 30 nov. 2014. 